\title{
Growth prediction for rubber tree and intercropped forest trees to facilitate environmental services valuation in South Thailand
}

\author{
NARUN NATTHAROM ${ }^{1, \boldsymbol{}}$, SAOWALAK ROONGTAWANREONGSRI ${ }^{1}$, SARA BUMRUNGSRI ${ }^{2}$ \\ ${ }^{1}$ Faculty of Environmental Management, Prince of Songkla University. 15 Karnjanavanich Rd., Hat Yai, Songkhla 90110, Thailand. Tel. +66-7428-6810, \\ Fax. +66-7442-9758, `email: narun.psu@gmail.com \\ ${ }^{2}$ Department of Biology, Faculty of Science, Prince of Songkla University. 15 Karnjanavanich Rd., Hat Yai, Songkhla 90110, Thailand
}

Manuscript received: 12 February 2020. Revision accepted: 15 April 2020.

\begin{abstract}
Nattharom N, Roongtawanreongsri S, Bumrungsri S. 2020. Growth prediction for rubber trees and intercropped forest trees to facilitate environmental services valuation in South Thailand. Biodiversitas 21: 2019-2034. Tree growth parameters are necessary for valuing ecological services of trees in both natural forest and agroforest. These parameters are difficult to measure annually, and thus often lack the information needed in valuation. This study aimed to use regression analysis to create growth models for diameter at breast height (DBH), total height (TH), and merchantable height (MH) of Hevea brasiliensis Mull-Arg. (rubber tree) and five economic forest trees that are preferred by rubber farmers for intercropping, including Hopea odorata Roxb., Shorea roxburghii G.Don., Swietenia macrophylla King., Dipterocarpus alatus Roxb., and Azadirachta excelsa (Jack) Jacobs. Data were collected from 39 rubber plantations that contain rubber trees and the intercropped tree species at different ages in three provinces in South Thailand. The data were modelled using regression analysis with curve fitting to find the best-fitted curve to a given set of points by minimizing the sum of the squares of the residuals and standard error of the regression of the points from the curve. The results arrived at 21 models for the DBH, TH, and $\mathrm{MH}$ growth of rubber and the intercropped trees, in the forms of, power, sigmoid and exponential trends that vary according to the type of trees. The models can be used to predict tree growth parameters, which are useful for determining the value of ecosystem services such as carbon dioxide sequestration, oxygen production, and timber production.
\end{abstract}

Keywords: Agroforest, ecosystem services, economic valuation, modelling tree growth, rubber and intercropping

Abbreviations: DBH: diameter at breast height, TH: total height, $\mathrm{MH}$ : merchantable height

\section{INTRODUCTION}

In southern Thailand, rubber (Hevea brasiliensis MullArg.) has been one of the most intensive commercial crops following the national policy to increase both yield and growth of the industry since 1960 (Rubber Authority of Thailand 2012). Recently, the global environmental movement has influenced many agencies, through projects such as Tree Bank (Bank for Agriculture and Agricultural Cooperatives 2015), Economic Forest Trees Planting Promotion Project for Economy, and the Society and Environmental Sustainability (Ministry of Natural Resources and Environment 2018), to encourage monoculture rubber farmers to diversify crop plants and thus alleviate climate change and improve ecosystems. One such approach is to adopt an agroforestry practice by intercropping rubber with other trees, aiming to increase diversity in the plantation. Adding intercropping to the rubber plantations can increase the potential for absorbing carbon from the atmosphere and storing it in different parts of the trees (Bumrungsri et al. 2011; Kumar and Nair 2011; Kittitornkool et al. 2014). It can improve the ecosystems, particularly by preventing soil erosion. The complexity of canopy between $H$. brasiliensis and intercropping helps reduce run-off (Witthawatchutikul 1993), while the complexity of root systems also helps the soil surface to adhere (Wibawa et al. 2007; Kittitornkool et al. 2014) and the high litterfalls in this plantation can increase nutrients in the soil (Wibawa et al. 2007; Bumrungsriet al. 2011). Often, the government supported the intercropping by supplying seedlings of forest trees of economic value such as Hopea odorata Roxb. (takhian thong), Shorea roxburghii G.Don. (payom), Swietenia macrophylla King. (mahogany), Dipterocarpus alatus Roxb. (yang-na), and Azadirachta excelsa (Jack) Jacobs. (sadao-thiam) (Ministry of Natural Resources and Environment 2018). These species thus become the popular choices for rubber farmers as they serve the dual purposes of increasing additional income as well as increased ecosystem services (Kittitornkool et al. 2014). However, not much is known about how this adoption genuinely generates the overall ecosystem services to the local ecosystem. The research found in Thailand limited to studying trees' carbon storage at certain ages. For example, Bumrungsri et al. (2011) studied the carbon storage in 45-years-old agroforest rubber plantation and 15-years-old monoculture rubber plantation in Phatthalung province. Poosaksai et al. (2018) studied the carbon storage of Pterocarpus macrocarpus Kurz, H. odorata, Azadirachta indica A. Juss and A. excelsa aged 21 years old at Prachuap Khiri Khan province. To our knowledge, no study provides information for continual estimation.

Recognition of ecosystem service value in terms of the monetary unit helps to make better decisions in allocating 
limited resources efficiently (Barbier et al. 2009). In forest and agroforest ecosystems, a variety of ecosystem services are generated, primarily carbon sequestration, oxygen production (Yolasiğmaz and Keleş 2009), soil erosion protection (Kittitornkool et al. 2014), and microclimate control (Bumrungsri et al. 2011). To value these ecosystem services, tree growth parameters are needed to be quantified before converting to monetary value. These parameters are diameter at breast height $(\mathrm{DBH})$, total height $(\mathrm{TH})$ and merchantable height $(\mathrm{MH})$ (Brown et al. 1989; Takimoto et al. 2008; Bumrungsri et al. 2011; Villeamor et al. 2014). However, annually measuring tree growth parameters is extremely effort demanding (Cao 2004); therefore, the availability of such data is scarce, making it challenging to calculate the economic value. Hence, being able to estimate these parameters at the tree age where the value is accounted would facilitate the economic valuation. Otherwise, the unavailability of this information would limit the accuracy of the economic valuation of the aforementioned ecosystem services.

In southern Thailand, in particular, the climate here is a tropical rainforest climate, with high annual rainfall (Lohmann et al., 1993). This condition generally results in trees in this region having a larger size than other areas in Thailand of the same age, particularly $H$. brasiliensis (Rubber Research Institute of Thailand 2018). That is because the climate influences the growth of the tree (Toledo et al. 2011; Ciceu et al. 2020). Thus, tree growth parameters from different regions or climates may underestimate the values of ecosystem services in the southern region. Furthermore, most of the research on tree growth in Thailand often uses data from experimental fields. The species of intercropped trees in the actual plantations have not yet been studied to cover the DBH, $\mathrm{TH}$, and MH. The results of the research, for example, by Sathapong (1970) and Sakai et al. (2010), were usually reported as raw data, without any attempt to create a model to predict tree growth for aiding economic valuation.

In order to overcome such an obstacle, it is necessary to be able to forecast the tree growth parameters at any particular age. Tree growth usually depends on their growth rate, which in turn often relates to tree age. Thus, if the growth rate can be determined, the tree growth parameters at a particular age can then be estimated. One approach is, therefore, to generate a regression model using the relationship between the growth rate and the age of the tree to forecast the $\mathrm{DBH}, \mathrm{TH}$, and $\mathrm{MH}$. Current literature shows that research on the growth rate of a rubber tree and particular economic forest trees favored by rubber farmers in southern Thailand is lacking. In other words, there are no specific models to estimate the tree growth parameters of those trees at a particular age. Three studies in different regions of Thailand reported the growth in the form of diameter, but they did not generate predictive models (Hongthong 1991; Visaratana et al. 1991; Sathapong 1970). These were the studies of the diameter of one-year-old seedlings Dalbergia cochinchinensis Pierre, Afzelia xylocarpa (Kurz), D. alatus, and H.odorata under canopy of Leucaena leucocephala (Lamk.) De Wit at Nakhon
Ratchasima province (Visaratana et al. 1991); the study of DBH and TH of 17-year-old H. odorata planted with Senna siamea (Lam.) Irwin \& Barne and D. alatus planted with $L$. leucocephala at Nakhon Ratchasima province (Sakai et al. 2010); and the study of DBH and TH of S. macrophylla at Prachuap Khiri Khan province (Sathapong 1970). In the southern region, we found the study of saplings diameter of one-year-old D. alatus, Dipterocarpus gracilis Blume, Dipterocarpus dyeri Pierre ex Laness., Parashorea stellata Kurz, H. odorata and Cotylelobium lanceolatum Craib under canopy of Acacia auriculiformis A. Cunn. ex Benth. at Surat Thani (Hongthong 1991) and the DBH study of 4.5 to 9-year-old S. macrophylla and A. excelsa was planted with $H$. brasiliensis at Songkhla, Krabi and Yala provinces.

This research intended to develop models for predicting $\mathrm{DBH}, \mathrm{TH}$, and $\mathrm{MH}$ at any particular age for individual rubber trees and rubber farmers' preferred economic forest tree species. Five species of economic trees were $H$. odorata, S. roxburghii, S. macrophylla, D. alatus, and A. excelsa in rubber plantations in southern Thailand. These species of intercropped trees are commonly grown in southern Thailand because of the government's support for the seedlings and techniques for planting these trees and because they are high-value trees. The results of the study can be used to assist in valuing ecosystem services more accurately, which consequently would assist the policymakers. Furthermore, plantation managers and economists can use this information for better farm management.

\section{MATERIALS AND METHODS}

\section{Study area}

The researchers used a snowballing method from experts who work with rubber farms to identify the rubber farmers who were already intercropping economic trees with rubber. To our knowledge, there were not many rubber farms with intercropped economic forest trees in southern Thailand (Kittitornkool et al. 2014). This situation restricts the number of plots and trees used in this study. The total of such plantations were 39 in Songkhla, Phatthalung, and Trang provinces $\left(5^{\circ} 57^{\prime}\right.$ to $10^{\circ} 59^{\prime} \mathrm{N}$ and $98^{\circ} 11^{\prime}$ to $102^{\circ} 04^{\prime} \mathrm{E}$ ) (Figure 1 ). Generally, they were a small-scale plantation with the area between $0.48-0.8$ ha. The plantations located below $100 \mathrm{~m}$ elevations, with the annual rainfall between $1,600-2,400 \mathrm{~mm}$ on average (Climatological Center 2020). Detail of these sites is shown in Table 1. These farms had non-uniform but similar intercropping practices. Usually, intercropped trees were planted when rubber trees reach the age of four. Farmers often planted single or mixed species of economic trees in one row, alternating with rubber trees in several rows. The space between rows of rubber trees was $3 \mathrm{~m}$, and the space between economic trees and rubber trees was $3.5 \mathrm{~m}$. The average number of economic trees was 238 trees $^{\mathrm{ha}^{-1}}$ in each plantation, whereas the average number of rubber trees was 475 . 


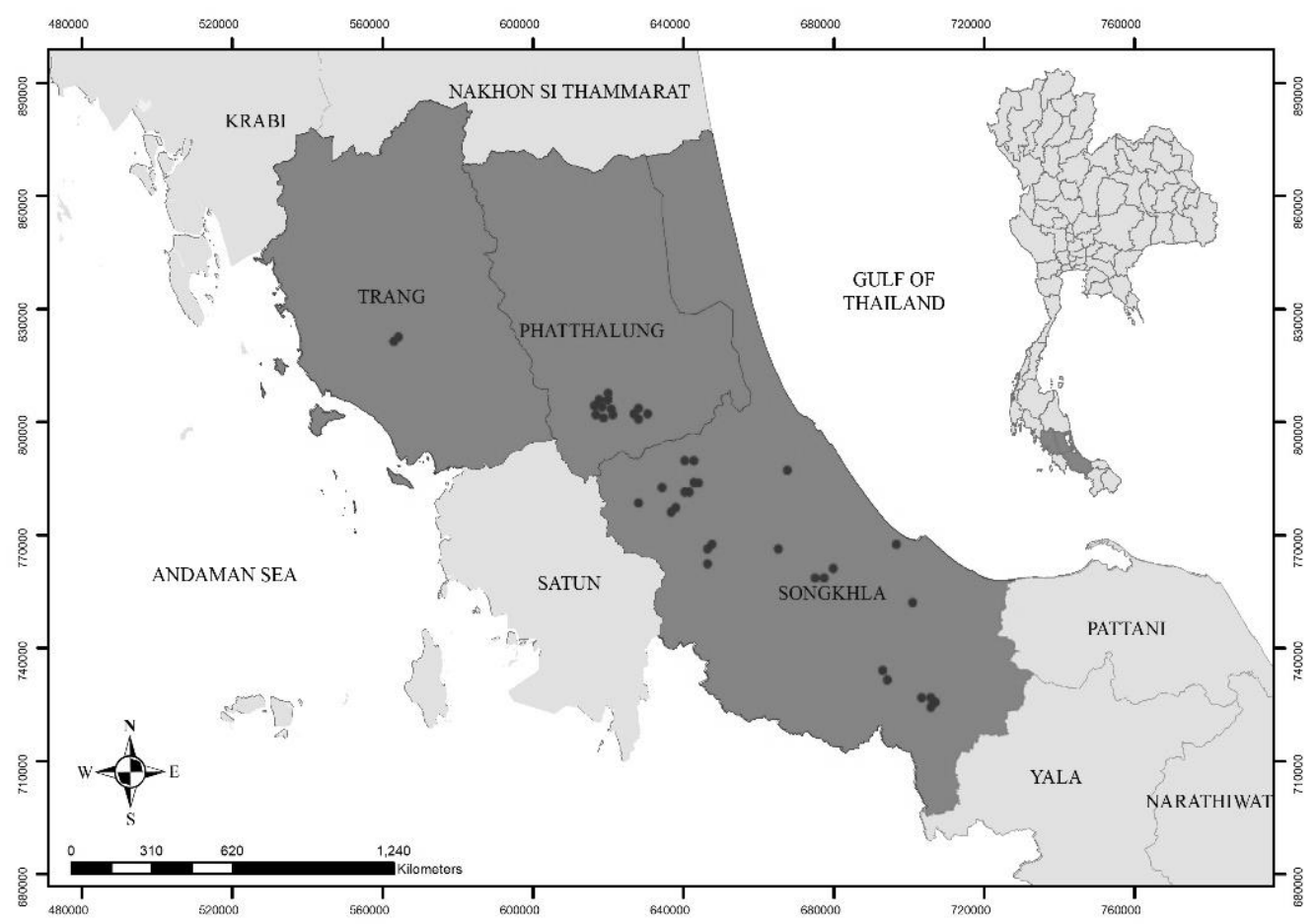

Figure 1. Locations of examined rubber plantations are shown by the black dot

\section{Tree sampling and growth measurement}

Trees at different ages were sampled depending on the number of trees in the plantation. If the total number of trees in each species in any plantation was less than 30 , all trees were measured for their growth parameters. The figure of 30 is an arbitrary number corresponding to the time limitation of the research. However, if the total number was more than 30 , a simple random sampling was used to select the rows of trees. Rows of trees were sampled randomly (using a random number generator app on a mobile phone). Every tree on that row was then measured. The row sampling was repeated until the number of each species sufficed.

$\mathrm{DBH}$ was measured using a measurement tape at the $130 \mathrm{~cm}$ height. TH and $\mathrm{MH}$ measurements were done by using a measuring pole (with the resolution of $0.1 \mathrm{~m}$ ) if a tree height was below $10 \mathrm{~m}$ and a hypsometer (Nikon Forestry Pro, with the resolution of $0.2 \mathrm{~m}$ ) if a tree height exceeded $10 \mathrm{~m}$. TH is the distance along the axis of the bole of the tree from the ground to the uppermost point (tip), whereas $\mathrm{MH}$ is the distance from the base of the tree to the first branching or other defects of the tree (Brack 1999).

Before sampling and measuring the tree size, the farmers who own the plantation were interviewed about the number of trees, age, and planting system of each tree species in the plantation. They were also asked to give observations from their experience on the growth of each tree species.

\section{The number of measured trees}

When $H$. brasiliensis is about seven years old, it is a common practice that farmers usually start tapping. The tapping of latex causes the tree to lose carbon which is a structural material and the source of metabolic energy for the growth process (Silpi et al. 2006). Since tapping is known to reduce the tree growth rate (Silpi et al. 2006), $H$. brasiliensis was separated into two groups: the trees before tapping (1-7 years) (140 trees) and the trees after tapping (> 7 years) (725 trees). For intercropped trees, there were $H$. odorata (521 trees), $S$. roxburghii (368 trees), $S$. macrophylla (243 trees), D. alatus (194 trees) and A. excelsa (131 trees) (Table 2).

\section{Modelling tree growth}

A linear regression analysis that is widely used to determine the tree's growth of each species (Linder 1981; Cao 2004; Westfall and Laustsen 2006; Saaludin et al. 2014) and curvilinear regression were used in this study (Gignac 2019). The curve estimation procedure was performed to find the model that best fits the data set. Previous works often suggest different but common types of model for age and growth relationship: linear (Saaludin et al. 2014), logarithm (Tamchai and Suksawang 2017), power (Forestry Research Center 2009), and exponential (Linder, 1981; Devaranavadgi et al. 2013). The models were fitted with these types of model. According to the shape of the scatter plot, the s-curve and growth models were also fitted. The key goodness-of-fit measures include the low standard error of the regression, the low total sum of square, low mean squared residuals, significant regression $p$-value, constant and significant coefficient $p$ values, and plausibly high adjusted R-square (but not necessarily the highest), as well as the non-systematic residuals plot (Wasserman 2004). 


\section{RESULTS AND DISCUSSION}

\section{Descriptive statistics results of the data}

Table 3 shows a summary of the descriptive statistics of the data of each species. Since the data set comprised trees from different ages from different plantations that may not start planting in the same year, the growth parameters were expected to show a wide range of variability. Few farmers started planting intercropped trees 20-30 years back; naturally, there were fewer numbers of older trees in the data set. This fact contributed to the data being scattered more in the younger years than the older years, thus giving the data a positive skew. Exceptions were found for the $\mathrm{TH}$ and $\mathrm{MH}$ of $H$. brasiliensis before tapping and $A$. excelsa, for which the data were slightly negatively skewed. The scatter plot and skewness of the data indicated that linear regression might not represent the best fit line; thus, curvilinear regression was performed.

\section{The regression models}

The results showed 21 models of the relationship between age and $\mathrm{DBH}, \mathrm{TH}$ and $\mathrm{MH}$ of the six species (Table 4 and Figure 2-4). For $H$. brasiliensis, the relationships between age and $\mathrm{DBH}, \mathrm{TH}$, and $\mathrm{MH}$ before and after tapping yielded similar patterns: power for DBH and $\mathrm{TH}$, and exponential for $\mathrm{MH}$. The goodness-of-fit parameters of the $\mathrm{MH}$ models did not differ much between power and exponential functions: i.e., for the $H$. brasiliensis before tapping, the standard error of the estimate for power and exponential functions were .192 and .190, and the MSE .037 and .036, respectively (Table $5)$. Therefore, either function could be selected. The same pattern was found for $H$. brasiliensis after tapping too. However, the model with the lowest statistical measures of the goodness-of-fit was chosen as a predictive model. For H. odorata, S. macrophylla, and D. alatus, the relationships were all in the form of exponential across all growth parameters. For $S$. roxburghii, the $\mathrm{DBH}$ took a power function while the $\mathrm{TH}$ and $\mathrm{MH}$ took exponential functions. All relationships between age and tree growth of A. excelsa were Sigmoid.

\section{The implication for economic valuation}

The ecosystem services from the forest, particularly carbon dioxide sequestration, oxygen production, and timber provisioning service, require the parameters of growth size. For instance, to calculate carbon dioxide sequestration, the biomass increment is needed. Here is an example: carbon dioxide sequestration $=($ BIT $\mathrm{x} 0.47) \mathrm{x}$ 3.67; where BIT is biomass increment, 0.47 is carbon conversion factor (Eggleston et al. 2014), and 3.67 is carbon dioxide conversion factor (Meepol 2010). Or, the oxygen production is estimated by this equation: oxygen production $=$ BIT $\times 1.2$; where BIT is biomass increment, 1.2 is the oxygen conversion factor (Yolasiğmaz and Keleş, 2009). The biomass is calculated using DBH and TH, for example:

$\mathrm{W}_{\mathrm{t}}=0.0046\left(\mathrm{DBH}^{2} \times \mathrm{TH}\right)^{1.2046}$ for $H$. brasiliensis (Trephattanasuwan et al. 2008);

$$
\mathrm{W}_{\mathrm{t}}=0.0241\left(\mathrm{DBH}^{2} \times \mathrm{TH}\right)^{1.0842} \text { for } H \text {. odorata }
$$

(Viriyabuncha et al. 2004); and $0.0435\left(\mathrm{DBH}^{2} \mathrm{x} \text { TH }\right)^{0.9370}$ for A. excelsa (Viriyabuncha et al. 2004);

$\mathrm{W}_{\mathrm{s}}=0.0509\left(\mathrm{DBH}^{2} \mathrm{x} \mathrm{TH}\right)^{0.919} ; \mathrm{W}_{\mathrm{b}}=0.00893\left(\mathrm{DBH}^{2} \mathrm{x}\right.$ $\mathrm{TH})^{0.977} ; \mathrm{W}_{\mathrm{l}}=0.0140\left(\mathrm{DBH}^{2} \mathrm{x} \mathrm{TH}\right)^{0.669}$; and $\mathrm{W}_{\mathrm{t}}=\mathrm{W}_{\mathrm{s}}+\mathrm{W}_{\mathrm{b}}$ $+\mathrm{W}_{1}$ for $S$. roxburghii, S. macrophylla, D. alatus and A. excelsa (Tsutsumi et al. 1983);

Where: $\mathrm{DBH}$ is the diameter at breast height, $\mathrm{TH}$ is total height, $\mathrm{W}_{\mathrm{s}}$ is stem biomass, $\mathrm{W}_{\mathrm{b}}$ is branch biomass, $\mathrm{W}_{\mathrm{l}}$ is leaf biomass, and $\mathrm{W}_{\mathrm{t}}$ is above-ground biomass.

The calculation of tree volume also requires $\mathrm{DBH}$ and $\mathrm{MH}$ parameters. For example, $\mathrm{V}=0.42 \times \mathrm{BA} \times \mathrm{MH}$; where $\mathrm{V}$ is timber volume, 0.42 is the coefficients of a tree stem's shape, BA is a tree's basal area at breast height (using DBH to calculate) and $\mathrm{MH}$ is a tree's merchantable height (Magnussen 2004).

The prediction models from this study are thus useful in such calculations. For example, we can calculate the benefits of carbon sequestration, oxygen production or timber volume of $S$. macrophylla at the age of 20 by using the predicting results in Tables 6 and 7 to estimate the growth size before calculating the relevant amount of ecosystem services. The economic value of these services can then be estimated once the price of the services is multiplied. Table 8 shows an example of applying the results of the prediction models to estimate the carbon dioxide sequestration, oxygen production and timber values of each species at the age of 10 and 20 years.

\section{Discussion}

This current study generated 21 models of the relationships between $\mathrm{DBH}, \mathrm{TH}$, and $\mathrm{MH}$ of six species. Although the current study is based on a small sample of participants, its findings can fill the research gap for now. In the future, when farmers grow more trees or when the data avails, the sample size of economic tree species should be increased. Although the sample size was small, the data varied over a wide range, attributable to the different managements in each plantation such as fertilization pattern and thinning. For example, different thinning patterns may affect the variability of MH of $H$. brasiliensis. Although thinning can increase tree size initially, after rubber tapping, the branches are too high for farmers to trim, thus allowing the tree to branch freely and reducing its size (Fernández et al. 2017). Therefore, similar heights cannot be expected in each plantation, and a wide range of $\mathrm{MH}$ thus inevitable. Because of this variability of $\mathrm{MH}$ data, the model of rubber trees after tapping results in the models' goodness-of-fit measures highest in terms of error. Another possible explanation for this is that the number and the age distribution of $H$. brasiliensis were much higher and broader than that of the economic forest tree species. This is because planting economic forest trees with rubber is still generally rare in Thailand. At present, from the researchers' interviews with farmers, $H$. odorata, $S$. roxburghii and $S$. macrophylla are the most popular trees because of their high economic values and suitability to grow under the canopy of $H$. brasiliensis. It is thus reflected in the lower number of plants grown in the plantations and made the total number of each economic tree species lower than that of the $H$. brasiliensis. 

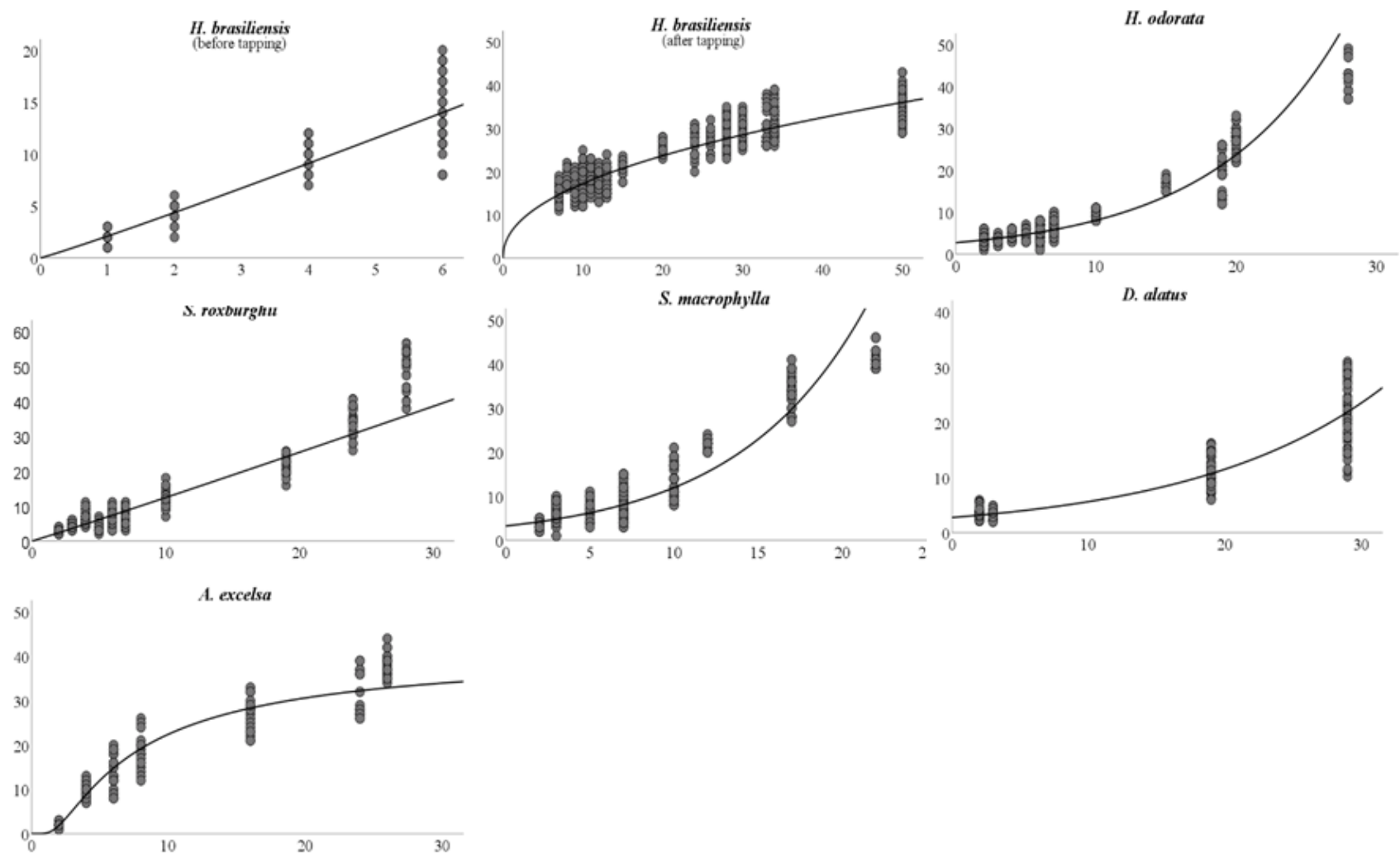

Figure 2. Relationship between DBH and age of trees
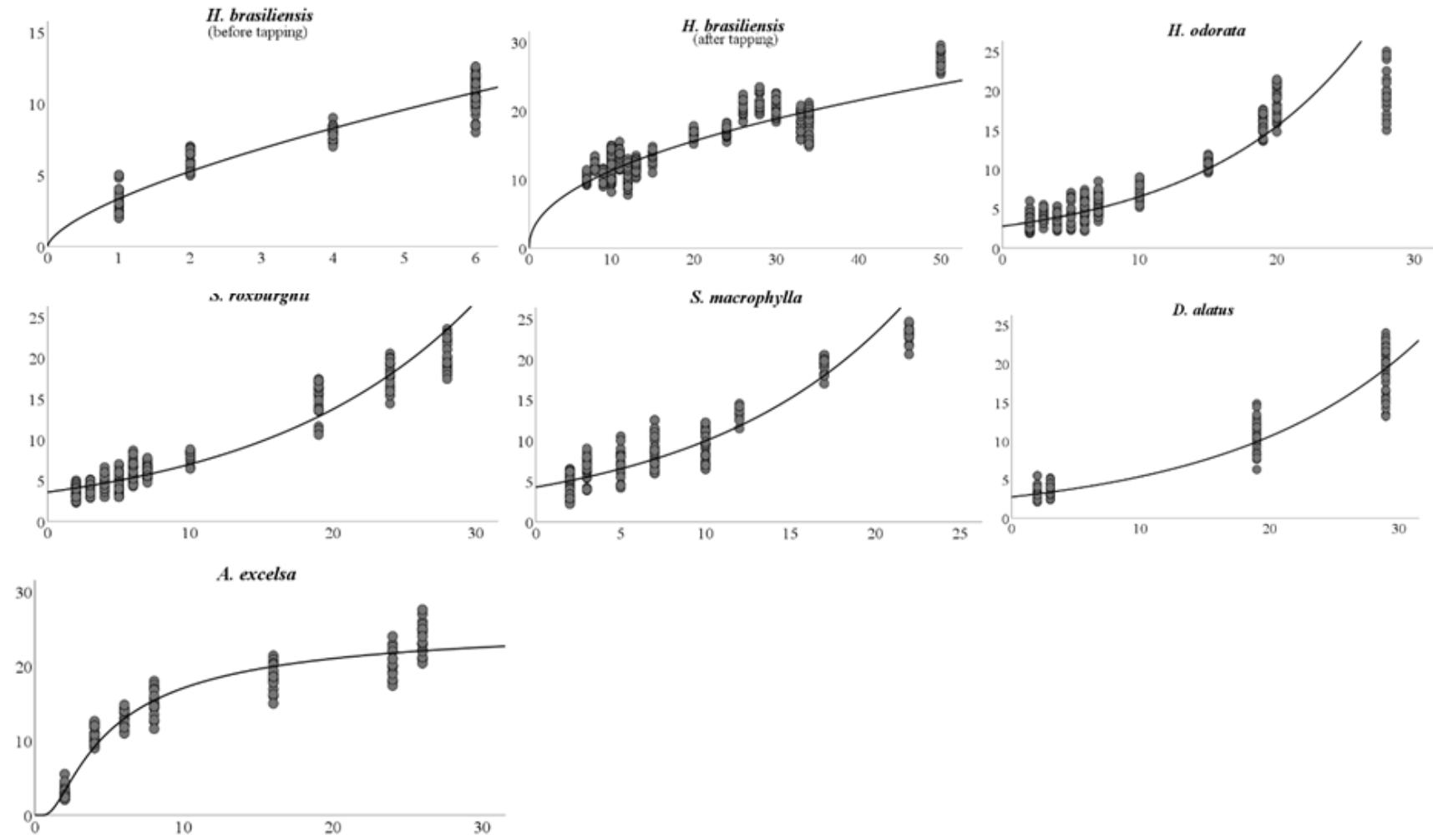

Figure 3. Relationship between $\mathrm{TH}$ and age of trees 


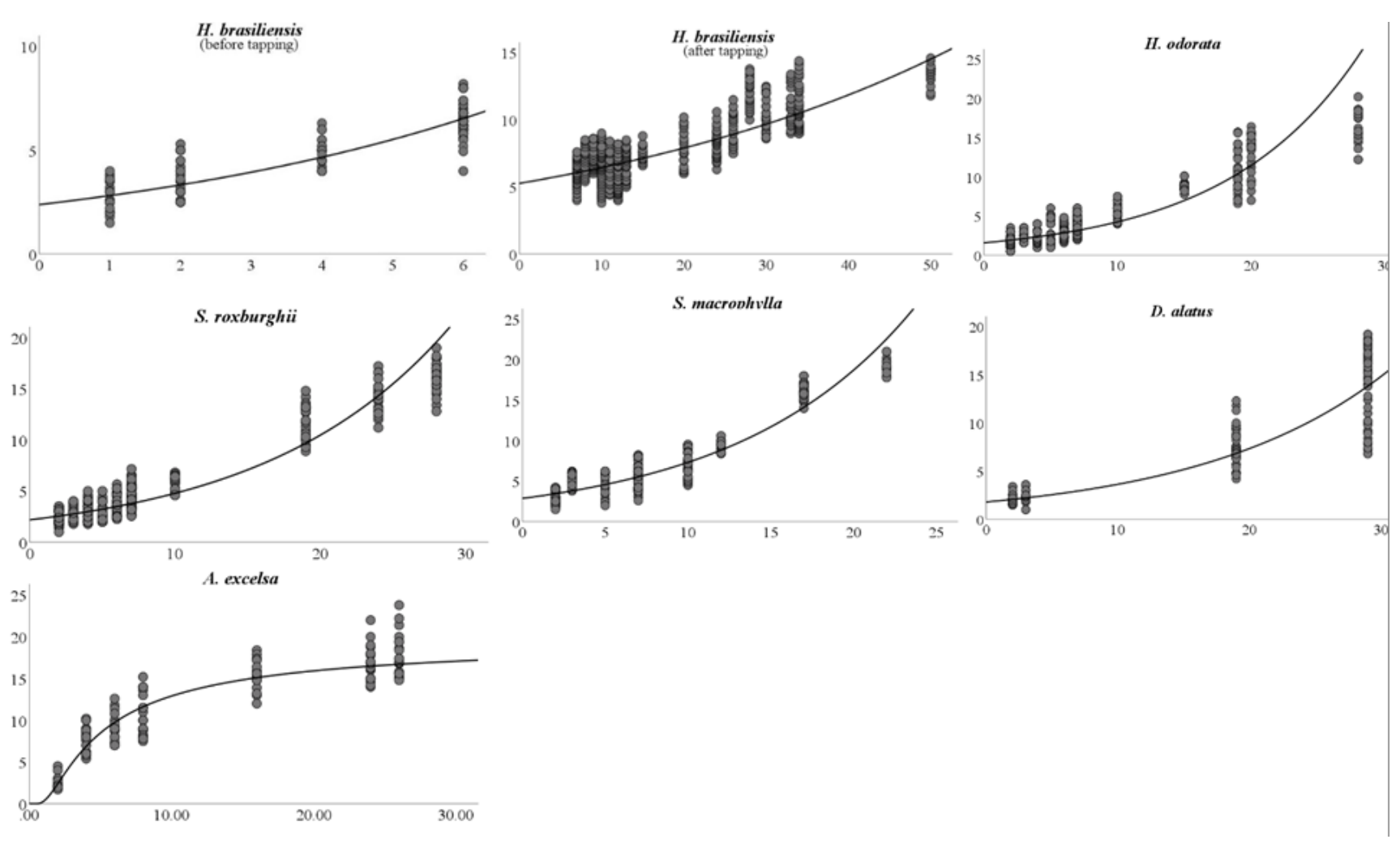

Figure 4. Relationship between MH and age of trees

Table 7 shows the differences in growth patterns which can be explained by the different characteristics of each species, the management of the plantations (Forestry Research Center 2009), genetic variation, and environmental conditions (Roo et al. 2014). The results showed that the growth rate of intercropping was high even though the density of $H$. brasiliensis in this research was as high as 475 trees ha $^{-1}$. The density was recommended by the Rubber Authority of Thailand (2018) and was a common practice in Thailand, whereas, in some countries, the density was only at 400 trees $^{-1}$ (Priyadarshan 2011). Despite that, the growth rate was still high, probably because of the differences in the depth of the root systems of $H$. brasiliensis and the intercropping. Usually, $H$. brasiliensis has the root system in the soil at a depth not exceeding 0.45 meters (Chugamnerd 1998; George et al. 2009), whereas the intercropping trees have a deep root system (Charernjiratragul et al. 2015) at one meter (Maeght 2013). Therefore, the nutrient competition between $H$. brasiliensis and the intercropping is low. In addition, the soil in rubber plantations with intercropping is more fertile than that in monoculture systems (Bumrungsri et al. 2011). This is due to high litterfall from a variety of species and more nutrients added to the soil because of a high number of trees (Wibawa et al. 2007; Bumrungsriet al. 2011). The complexity of the canopy and the root system in the plantation can reduce soil erosion (Witthawatchutikul 1993; Wibawa et al. 2007; Kittitornkool et al. 2014) which therefore can preserve the nutrients necessary for the growth of trees. Furthermore, the high canopy cover helps maintain air temperature (Yunis et al. 1990; Brooks and Kyker-Snowman. 2008) and soil moisture (Islam et al. 2016; Özkan and Gökbulak, 2017) in which the accelerated rate of litter decomposition becomes soil nutrients (Golley 1983; Swift and Anderson 1989).

To test the accuracy of the models, we compared the predicted results of the models to the observed data available in the presently scarce literature. Due to the limited data availability, uniformed comparisons for each species and each growth parameter were not possible. Whereas the verification of five out of six species can be done with the $\mathrm{DBH}$, it was not possible with the $\mathrm{TH}$, possibly because measuring tree height is difficult, and usually entails much error (Luoma et al. 2017). The predicted DBH of $H$. brasiliensis, S. macrophylla and A. excelsa were compared to the data from the Rubber Research Institute's experimental monoculture plots in the southern region, whereas $H$. odorata, and $D$. alatus were compared to the data from the experimental plots in the northeastern region. The predicted TH of S. macrophylla, $H$. odorata, and D. alatus were also compared to the data from the experimental plots outside the southern region. 
Table 1. Summary of the site characteristics

\begin{tabular}{|c|c|c|c|c|c|c|c|c|c|c|c|c|c|c|c|c|c|}
\hline \multirow[b]{2}{*}{ Province } & \multirow{2}{*}{$\begin{array}{c}\text { Average annual } \\
\text { precipitation }(\mathbf{m m}) \\
\text { and temperature }\left({ }^{\circ} \mathrm{C}\right)\end{array}$} & \multirow[b]{2}{*}{ Species } & \multirow[b]{2}{*}{ Age } & \multirow{2}{*}{$\begin{array}{c}\text { Number } \\
\text { of sites }\end{array}$} & \multirow{2}{*}{$\begin{array}{c}\text { Number } \\
\text { of tree }\end{array}$} & \multicolumn{4}{|c|}{ DBH (cm) } & \multicolumn{4}{|c|}{ TH (m) } & \multicolumn{4}{|c|}{ MH (m) } \\
\hline & & & & & & Min & $\operatorname{Max}$ & Mean & S.D. & Min & $\operatorname{Max}$ & Mean & S.D & Min & Max & Mean & S.D. \\
\hline \multirow[t]{6}{*}{ Songkhla } & $1,600-2,000$ & H. brasiliensis & $6-34$ & 30 & 510 & 7.9 & 37.9 & 19.6 & 5.5 & 7.8 & 22.4 & 13.0 & 3.4 & 3.0 & 14.0 & 7.1 & 1.9 \\
\hline & $26-28$ & H. odorata & $2-28$ & 16 & 434 & 1.0 & 48.6 & 8.6 & 9.0 & 1.9 & 25.0 & 6.4 & 4.6 & 0.5 & 20.2 & 4.4 & 3.9 \\
\hline & & S. roxburghii & $2-28$ & 10 & 278 & 1.6 & 56.5 & 14.2 & 15.4 & 2.3 & 23.5 & 8.5 & 6.2 & 1.0 & 19.0 & 6.3 & 5.3 \\
\hline & & S. macrophylla & $2-22$ & 8 & 183 & 1.3 & 45.9 & 15.1 & 13.3 & 2.2 & 24.6 & 10.4 & 6.5 & 1.5 & 21.0 & 8.1 & 5.6 \\
\hline & & D. alatus & $2-29$ & 6 & 144 & 2.0 & 31.0 & 11.6 & 10.1 & 2.1 & 24.0 & 10.0 & 7.8 & 1.0 & 19.2 & 7.3 & 6.2 \\
\hline & & A. excelsa & $2-26$ & 6 & 111 & 1.0 & 44.4 & 21.7 & 12.8 & 2.1 & 27.6 & 15.6 & 6.8 & 1.7 & 23.8 & 12.1 & 5.7 \\
\hline \multirow[t]{5}{*}{ Phattalung } & $2,000-2,400$ & H. brasiliensis & $1-50$ & 10 & 300 & 1.0 & 43.3 & 17.9 & 10.8 & 2.0 & 29.6 & 13.2 & 7.3 & 1.5 & 14.6 & 7.6 & 3.5 \\
\hline & $26-28$ & H. odorata & $7-20$ & 3 & 87 & 3.0 & 3.3 & 13.1 & 9.8 & 3.4 & 21.4 & 9.5 & 6.5 & 2.0 & 16.4 & 6.5 & 4.6 \\
\hline & & S. roxburghii & $6-7$ & 3 & 90 & 3.0 & 11.4 & 6.9 & 1.9 & 4.3 & 8.7 & 6.3 & 0.9 & 2.3 & 7.2 & 4.3 & 1.1 \\
\hline & & S. macrophylla & 7 & 2 & 60 & 3.0 & 15.3 & 8.4 & 3.5 & 6.0 & 12.5 & 8.4 & 1.8 & 2.6 & 8.2 & 5.4 & 1.5 \\
\hline & & A. excelsa & 6 & 1 & 20 & 7.8 & 19.8 & 14.2 & 3.8 & 11.0 & 14.8 & 13.0 & 1.2 & 7.0 & 12.6 & 9.1 & 1.6 \\
\hline \multirow[t]{2}{*}{ Trang } & $2,000-2,400$ & H. brasiliensis & $24-34$ & 2 & 60 & 24.0 & 34.0 & 29.0 & 5.0 & 20.2 & 35.0 & 28.5 & 2.6 & 6.3 & 10.6 & 8.7 & 0.9 \\
\hline & $26-28$ & D. alatus & 19 & 1 & 30 & 6.0 & 16.2 & 11.3 & 3.1 & 6.3 & 14.8 & 11.0 & 2.0 & 4.2 & 12.3 & 7.6 & 2.0 \\
\hline
\end{tabular}


Table 2. Number of trees studied

\begin{tabular}{lcccccc}
\hline \multirow{2}{*}{ Tree } & \multicolumn{5}{c}{ Number of studied trees (number of plantations) } \\
\cline { 2 - 6 } & 1-10 year & $\mathbf{1 1 - 2 0}$ year & $\mathbf{2 1 - 3 0}$ year & $\mathbf{3 1 - 4 0}$ year & 41-50 year & Total \\
\hline H. brasiliensis & $371(13)$ & $240(9)$ & $120(4)$ & $104(4)$ & $30(1)$ & 865 \\
H. odorata & $413(16)$ & $88(4)$ & $20(1)$ & - & - & 521 \\
S. roxburghii & $290(11)$ & $25(1)$ & $53(2)$ & - & - & 368 \\
S. macrophylla & $188(10)$ & $40(2)$ & $15(1)$ & - & - & 243 \\
D. alatus & $96(5)$ & $41(2)$ & $57(3)$ & - & - & 194 \\
A. excelsa & $73(4)$ & $19(1)$ & $39(2)$ & - & - & 131 \\
\hline
\end{tabular}

Note: The age of trees were from the farmers who kept track of the planting year

Table 3. Descriptive analysis results of the data set

\begin{tabular}{|c|c|c|c|c|c|c|c|c|}
\hline \multirow{2}{*}{ Tree } & \multicolumn{8}{|c|}{ Descriptive statistics } \\
\hline & $\mathbf{N}$ & Growth variable & Min & Max & Mean & S.D. & Skewness & Kurtosis \\
\hline H. brasiliensis & 140 & $\mathrm{DBH}$ & 1.00 & 20.00 & 8.8667 & 5.25161 & .228 & -.989 \\
\hline \multirow[t]{2}{*}{ before tapping } & & $\mathrm{TH}$ & 2.00 & 12.60 & 7.7353 & 3.01765 & -.258 & -1.052 \\
\hline & & MH & 1.50 & 8.20 & 4.8300 & 1.66998 & -.117 & -1.065 \\
\hline H. brasiliensis & 725 & $\mathrm{DBH}$ & 8.00 & 43.00 & 21.8458 & 6.59708 & .590 & -.348 \\
\hline \multirow[t]{2}{*}{ after tapping } & & $\mathrm{TH}$ & 7.80 & 29.60 & 14.4688 & 4.63903 & 1.040 & .600 \\
\hline & & MH & 3.80 & 14.60 & 7.9338 & 2.36314 & .817 & .101 \\
\hline \multirow{3}{*}{ H. odorata } & 521 & $\mathrm{DBH}$ & 1.00 & 49.00 & 9.3205 & 9.31722 & 2.219 & 4.653 \\
\hline & & $\mathrm{TH}$ & 1.90 & 25.00 & 6.9555 & 5.12045 & 1.586 & 1.515 \\
\hline & & MH & 0.50 & 20.20 & 4.7560 & 4.07007 & 1.692 & 2.149 \\
\hline \multirow[t]{3}{*}{ S. roxburghii } & 368 & $\mathrm{DBH}$ & 2.00 & 56.53 & 12.4330 & 13.81831 & 1.840 & 2.280 \\
\hline & & $\mathrm{TH}$ & 2.30 & 23.50 & 7.9568 & 5.48044 & 1.376 & .516 \\
\hline & & MH & 1.00 & 19.00 & 5.8021 & 4.68275 & 1.371 & .479 \\
\hline \multirow[t]{3}{*}{ S. macrophylla } & 243 & $\mathrm{DBH}$ & 1.00 & 46.00 & 13.3868 & 12.00648 & 1.264 & .272 \\
\hline & & $\mathrm{TH}$ & 2.20 & 24.60 & 9.8782 & 5.73561 & 1.082 & .074 \\
\hline & & $\mathrm{MH}$ & 1.50 & 21.00 & 7.4374 & 5.04834 & 1.249 & .301 \\
\hline \multirow[t]{3}{*}{ D. alatus } & 174 & $\mathrm{DBH}$ & 1.97 & 31.00 & 11.5709 & 9.27484 & .755 & -.793 \\
\hline & & $\mathrm{TH}$ & 2.10 & 24.00 & 10.2144 & 7.14712 & .433 & -1.249 \\
\hline & & $\mathrm{MH}$ & 1.00 & 19.20 & 7.3227 & 5.70456 & .714 & -.846 \\
\hline \multirow[t]{3}{*}{ A. excelsa } & 131 & $\mathrm{DBH}$ & 1.00 & 44.00 & 20.5496 & 12.17514 & .092 & -1.148 \\
\hline & & $\mathrm{TH}$ & 2.10 & 27.60 & 15.2374 & 6.35854 & -.389 & -.434 \\
\hline & & $\mathrm{MH}$ & 1.70 & 23.80 & 11.6622 & 5.41815 & -.117 & -.871 \\
\hline
\end{tabular}

Table 9 shows different approximation between the predicted and the observed DBH and TH. The results of the DBH and TH prediction for $H$. brasiliensis, $S$. macrophylla, and D. alatus appear to be lower than the available studies. One possible explanation is that the data from other studies were from the controlled monoculture experimental plots, whereas the data in this study came from a variety of actual intercropping plantations which differ in micro-environmental conditions. In controlled experimental plots, the environment where trees were grown was similar; therefore, trees generally produced similar sizes in a similar age range. In contrast, the actual plantations were growing in different environmental conditions; thus, trees were different in size and age. Another vital explanation of the lower growth rate from the prediction models is the tapping systems. In this study, the farmers applied the higher-frequency tapping system (3days tapping followed by 1-day rest), while the controlled plots applied the alternate daily tapping. The high frequency of the tapping system may slow the $H$. brasiliensis growth rate down (Rubber Research Institute of Thailand 2018). The predicted DBHs of A. excelsa were higher than one study but lower than another study, whereas the $\mathrm{TH}$ was slightly higher than the only study found. Note that the prediction of S. macrophylla in the study area suggested a higher growth rate at the older ages than in the literature, which may be related to precipitation. For example, Shono and Snook (2006) found that the growth rate of $S$. macrophylla increased according to the annual precipitation. In this study area, the annual precipitation $(1,600-2,400 \mathrm{~mm})$ is higher than some other studies: southeast Para'state, Brazil 1,859 mm (Grogan et al. 2010), Quintana Roo, Mexico $1300 \mathrm{~mm}$ (Roo et al. 2014), and northwestern Belize, Mexico $1600 \mathrm{~mm}$ (Shono and Snook 2006). This may contribute to the reason that $S$. macrophylla growth rates in this study were high.

To our knowledge, there is no available model to predict $\mathrm{MH}$ in Thailand for these species that were included in this study. Unlike other ecosystem services, $\mathrm{MH}$ is the parameter that the farmers are most interested in 
because it is more tangible than carbon storage or oxygen production. Thus it is significant for them to be able to predict the $\mathrm{MH}$ and calculate this provisioning service. The contribution of this study is a tool that enables the farmers and relevant stakeholders to calculate this particular benefit of intercropping.

In conclusion, the tree growth prediction models of five species were generated, which can be used to predict the $\mathrm{DBH}, \mathrm{TH}$, and $\mathrm{MH}$ at any particular age. The contribution of these models provides a powerful tool for valuing ecosystem services from these trees at various ages more accurately, particularly those ecological service values that need a tree size in the calculation - primarily carbon sequestration, oxygen production, and wood production. Researchers, farmers, and policymakers can directly use the models to predict $\mathrm{DBH}, \mathrm{TH}$, and $\mathrm{MH}$ which would benefit future planning or promoting the intercropping in a rubber plantation to secure maximum benefit both financially and environmentally. The growth prediction of trees at any age can also benefit the project related to payment for ecosystem service too. However, due to the small-size sample of the economic trees, the application of the models to be used elsewhere must consider the tree species and the climatic conditions that are similar to our study area. Future research should include older trees and other tree species intercropped in the rubber plantation, which are constrained in this study. This is to promote environmentally friendly farming practices that serve for improving ecological benefits and contributing to the global effect.
Table 4. The models predicting tree growth parameters (DBH, $\mathrm{TH}, \mathrm{MH})$

\begin{tabular}{lll}
\hline \multicolumn{1}{c}{ Tree species } & \multicolumn{1}{c}{$\begin{array}{c}\text { Regression } \\
\text { type }\end{array}$} & \multicolumn{1}{c}{ Regression model } \\
\hline H. brasiliensis & Power & $\mathrm{DBH}=2.095 \mathrm{x}^{1.060}$ \\
(before tapping) & Power & $\mathrm{TH}=3.337 \mathrm{x}^{0.655}$ \\
& Exponential & $\mathrm{MH}=2.387 \mathrm{e}^{0.167 \mathrm{x}}$ \\
H. brasiliensis & Power & $\mathrm{DBH}=5.845 \mathrm{x}^{0.467}$ \\
(after tapping) & Power & $\mathrm{TH}=3.850 \mathrm{x}^{0.468}$ \\
& Exponential & $\mathrm{MH}=5.276 \mathrm{e}^{0.020 \mathrm{x}}$ \\
H. odorata & Exponential & $\mathrm{DBH}=2.748 \mathrm{e}^{0.108 \mathrm{x}}$ \\
& Exponential & $\mathrm{TH}=2.777 \mathrm{e}^{0.086 \mathrm{x}}$ \\
& Exponential & $\mathrm{MH}=1.575 \mathrm{e}^{0.099 \mathrm{x}}$ \\
S. roxburghii & Power & $\mathrm{DBH}=1.160 \mathrm{x}^{1.030}$ \\
& Exponential & $\mathrm{TH}=3.580 \mathrm{e}^{0.067 \mathrm{x}}$ \\
& Exponential & $\mathrm{MH}=2.190 \mathrm{e}^{0.078 \mathrm{x}}$ \\
S. macrophylla & Exponential & $\mathrm{DBH}=3.248 \mathrm{e}^{0.130 \mathrm{x}}$ \\
& Exponential & $\mathrm{TH}=4.281 \mathrm{e}^{0.084 \mathrm{x}}$ \\
& Exponential & $\mathrm{MH}=2.859 \mathrm{e}^{0.094 \mathrm{x}}$ \\
D. alatus & Exponential & $\mathrm{DBH}=2.746 \mathrm{e}^{0.072 \mathrm{x}}$ \\
& Exponential & $\mathrm{TH}=2.752 \mathrm{e}^{0.067 \mathrm{x}}$ \\
& Exponential & $\mathrm{MH}=1.801 \mathrm{e}^{0.070 \mathrm{x}}$ \\
A. excelsa & Sigmoid & $\mathrm{DBH}=\mathrm{e}^{3.733-6.227 / \mathrm{x}}$ \\
& Sigmoid & $\mathrm{TH}=\mathrm{e}^{3.253-4.147 / \mathrm{x}}$ \\
& Sigmoid & $\mathrm{MH}=\mathrm{e}^{2.978-4.204 / \mathrm{x}}$ \\
& &
\end{tabular}

$\mathrm{DBH}$; diameter at breast height, $\mathrm{TH}$; total height, $\mathrm{MH}$; merchantable height and $\mathrm{x}$; age of tree (year)

Table 5. Key goodness-of-fit measures for regression analysis of the models

\begin{tabular}{|c|c|c|c|c|c|c|c|c|}
\hline \multirow{2}{*}{ Tree species } & \multirow{2}{*}{ Type } & \multirow{2}{*}{$\begin{array}{l}\text { Adjusted } \\
\qquad \mathbf{R}^{\mathbf{2}}\end{array}$} & \multirow{2}{*}{$\begin{array}{l}\text { Std error of the } \\
\text { estimate }\end{array}$} & \multirow{2}{*}{$\begin{array}{c}\text { SST } \\
\text { (Total sum of } \\
\text { squares) } \\
\end{array}$} & \multirow{2}{*}{$\begin{array}{l}\text { Mean squared } \\
\text { residual }\end{array}$} & \multirow{2}{*}{$\begin{array}{c}\text { Model } \\
\text { Sig. }\end{array}$} & \multicolumn{2}{|c|}{ p value } \\
\hline & & & & & & & constant & b1 \\
\hline H. brasiliensi & $\mathrm{DBH}$ & & & & & & & \\
\hline \multirow[t]{18}{*}{ before tapping } & Linear & .826 & 2.193 & 4109.333 & 4.811 & .000 & 1.000 & .000 \\
\hline & Logarithm & .808 & 2.303 & 4109.333 & 5.306 & .000 & .001 & .000 \\
\hline & Power & .909 & .233 & 89.258 & .054 & .000 & .000 & .000 \\
\hline & $\mathrm{S}$ & .889 & .258 & 89.258 & .066 & .000 & .000 & .000 \\
\hline & Growth & .839 & .310 & 89.258 & .096 & .000 & .000 & .000 \\
\hline & $\begin{array}{l}\text { Exponential } \\
\text { TH }\end{array}$ & .839 & .310 & 89.258 & .096 & .000 & .000 & .000 \\
\hline & Linear & .898 & .963 & 1356.823 & .927 & .000 & .000 & .000 \\
\hline & Logarithm & .901 & .952 & 1356.823 & .906 & .000 & .000 & .000 \\
\hline & Power & .893 & .158 & 34.684 & .025 & .000 & .000 & .000 \\
\hline & $\mathrm{S}$ & .892 & .159 & 34.684 & .025 & .000 & .000 & .000 \\
\hline & Growth & .821 & .204 & 34.684 & .042 & .000 & .000 & .000 \\
\hline & $\begin{array}{l}\text { Exponential } \\
\text { MH }\end{array}$ & .821 & .204 & 34.684 & .042 & .000 & .000 & .000 \\
\hline & Linear & .792 & .761 & 415.535 & .579 & .000 & .000 & .000 \\
\hline & Logarithm & .755 & .827 & 415.535 & .684 & .000 & .000 & .000 \\
\hline & Power & .755 & .195 & 23.054 & .038 & .000 & .000 & .000 \\
\hline & S & .684 & .221 & 23.054 & .049 & .000 & .000 & .000 \\
\hline & Growth & .754 & .195 & 23.054 & .038 & .000 & .000 & .000 \\
\hline & Exponential & .754 & .195 & 23.054 & .038 & .000 & .000 & .000 \\
\hline
\end{tabular}




\begin{tabular}{|c|c|c|c|c|c|c|c|c|}
\hline \multirow[t]{19}{*}{ H. brasiliensi after tapping } & \multicolumn{8}{|l|}{ DBH } \\
\hline & Linear & .794 & 2.993 & 31291.888 & 8.957 & .000 & .000 & .000 \\
\hline & Logarithm & .808 & 2.888 & 31291.888 & 8.338 & .000 & .000 & .000 \\
\hline & Power & .776 & .142 & 64.858 & .020 & .000 & .000 & .000 \\
\hline & $\mathrm{S}$ & .734 & .155 & 64.858 & .024 & .000 & .000 & .000 \\
\hline & Growth & .725 & .157 & 64.858 & .025 & .000 & .000 & .000 \\
\hline & $\begin{array}{l}\text { Exponential } \\
\text { TH }\end{array}$ & .725 & .157 & 64.858 & .025 & .000 & .000 & .000 \\
\hline & Linear & .826 & 1.935 & 15473.282 & 3.746 & .000 & .000 & .000 \\
\hline & Logarithm & .786 & 2.145 & 15473.282 & 4.602 & .000 & .000 & .000 \\
\hline & Power & .793 & .135 & 63.863 & .018 & .000 & .000 & .000 \\
\hline & $\mathrm{S}$ & .709 & .161 & 63.863 & .026 & .000 & .000 & .000 \\
\hline & Growth & .787 & .138 & 63.863 & .019 & .000 & .000 & .000 \\
\hline & $\begin{array}{l}\text { Exponential } \\
\text { MH }\end{array}$ & .787 & .138 & 63.863 & .019 & .000 & .000 & .000 \\
\hline & Linear & .679 & 1.338 & 4015.210 & 1.791 & .000 & .000 & .000 \\
\hline & Logarithm & .618 & 1.461 & 4015.210 & 2.136 & .000 & .000 & .000 \\
\hline & Power & .576 & .187 & 59.497 & .035 & .000 & .000 & .000 \\
\hline & $\mathrm{S}$ & .468 & .210 & 59.497 & .044 & .000 & .000 & .000 \\
\hline & Growth & .615 & .179 & 59.497 & .032 & .000 & .000 & .000 \\
\hline & Exponential & .615 & .179 & 59.497 & .032 & .000 & .000 & .000 \\
\hline \multirow[t]{19}{*}{ H. odorata } & \multicolumn{8}{|l|}{$\mathrm{DBH}$} \\
\hline & Linear & .904 & 2.887 & 45141.470 & 8.332 & .000 & .000 & .000 \\
\hline & Logarithm & .660 & 5.434 & 45141.470 & 29.530 & .000 & .000 & .000 \\
\hline & Power & .811 & .332 & 302.319 & .110 & .000 & .000 & .000 \\
\hline & $\mathrm{S}$ & .557 & .507 & 302.319 & .257 & .000 & .000 & .000 \\
\hline & Growth & .859 & .286 & 302.319 & .082 & .000 & .000 & .000 \\
\hline & \multicolumn{8}{|l|}{$\mathrm{TH}$} \\
\hline & Linear & .903 & 1.597 & 13633.887 & 2.549 & .000 & .000 & .000 \\
\hline & Logarithm & .730 & 2.660 & 13633.887 & 7.073 & .000 & .000 & .000 \\
\hline & Power & .804 & .274 & 199.412 & .075 & .000 & .000 & .000 \\
\hline & $\mathrm{S}$ & .562 & .410 & 199.412 & .168 & .000 & .000 & .000 \\
\hline & Growth & .828 & .256 & 199.412 & .066 & .000 & .000 & .000 \\
\hline & $\begin{array}{l}\text { Exponential } \\
\text { MH }\end{array}$ & .828 & .256 & 199.412 & .066 & .000 & .000 & .000 \\
\hline & Linear & .894 & 1.328 & 8614.043 & 1.763 & .000 & .429 & .000 \\
\hline & Logarithm & .712 & 2.185 & 8614.043 & 4.775 & .000 & .000 & .000 \\
\hline & Power & .779 & .344 & 278.524 & .118 & .000 & .000 & .000 \\
\hline & $\mathrm{S}$ & .550 & .491 & 278.524 & .241 & .000 & .000 & .000 \\
\hline & Growth & .792 & .334 & 278.524 & .111 & .000 & .000 & .000 \\
\hline & Exponential & .792 & .334 & 278.524 & .111 & .000 & .000 & .000 \\
\hline \multirow[t]{19}{*}{ S. roxburghii } & \multicolumn{8}{|l|}{$\mathrm{DBH}$} \\
\hline & Linear & .919 & 3.935 & 70077.039 & 15.482 & .000 & .000 & .000 \\
\hline & Logarithm & .728 & 7.205 & 70077.039 & 51.973 & .000 & .000 & .000 \\
\hline & Power & .857 & .341 & 298.750 & .116 & .000 & .000 & .000 \\
\hline & $\mathrm{S}$ & .652 & .532 & 298.750 & .283 & .000 & .000 & .000 \\
\hline & Growth & .856 & .342 & 298.750 & .117 & .000 & .000 & .000 \\
\hline & \multicolumn{7}{|l|}{$\mathrm{TH}$} & .000 \\
\hline & Linear & .953 & 1.185 & 11022.907 & 1.405 & .000 & .000 & .000 \\
\hline & Logarithm & .823 & 2.303 & 11022.907 & 5.303 & .000 & .000 & .000 \\
\hline & Power & .878 & .204 & 124.757 & .042 & .000 & .000 & .000 \\
\hline & $\mathrm{S}$ & .625 & .357 & 124.757 & .128 & .000 & .000 & .000 \\
\hline & Growth & .887 & .196 & 124.757 & .038 & .000 & .000 & .000 \\
\hline & \multicolumn{7}{|l|}{$\mathrm{MH}$} & .000 \\
\hline & Linear & .945 & 1.100 & 8047.621 & 1.209 & .000 & .000 & .000 \\
\hline & Logarithm & .805 & 2.070 & 8047.621 & 4.238 & .000 & .000 & .000 \\
\hline & Power & .838 & .279 & 176.027 & .078 & .000 & .000 & .000 \\
\hline & $\mathrm{S}$ & .583 & .447 & 176.027 & .200 & .000 & .000 & .000 \\
\hline & Growth & .853 & .266 & 176.027 & .071 & .000 & .000 & .000 \\
\hline & Exponential & .853 & .266 & 176.027 & .071 & .000 & .000 & .000 \\
\hline
\end{tabular}




\begin{tabular}{|c|c|c|c|c|c|c|c|c|}
\hline \multirow[t]{19}{*}{ S. macrophylla } & \multicolumn{8}{|l|}{$\mathrm{DBH}$} \\
\hline & Linear & .899 & 3.808 & 34885.638 & 14.497 & .000 & .000 & .000 \\
\hline & Logarithm & .692 & 6.661 & 34885.638 & 44.365 & .000 & .000 & .000 \\
\hline & Power & .772 & .406 & 175.004 & .165 & .000 & .000 & .000 \\
\hline & $\mathrm{S}$ & .604 & .535 & 175.004 & .286 & .000 & .000 & .000 \\
\hline & Growth & .816 & .364 & 175.004 & .133 & .000 & .000 & .000 \\
\hline & $\begin{array}{l}\text { Exponential } \\
\text { TH }\end{array}$ & .816 & .364 & 175.004 & .133 & .000 & .000 & .000 \\
\hline & Linear & .897 & 1.842 & 7961.114 & 3.393 & .000 & .000 & .000 \\
\hline & Logarithm & .730 & 2.981 & 7961.114 & 8.888 & .000 & .003 & .000 \\
\hline & Power & .776 & .264 & 75.285 & .070 & .000 & .000 & .000 \\
\hline & S & .638 & .336 & 75.285 & .113 & .000 & .000 & .000 \\
\hline & Growth & .796 & .252 & 75.285 & .063 & .000 & .000 & .000 \\
\hline & $\begin{array}{l}\text { Exponential } \\
\mathrm{MH}\end{array}$ & .796 & .252 & 75.285 & .063 & .000 & .000 & .000 \\
\hline & Linear & .883 & 1.728 & 6167.549 & 2.985 & .000 & .000 & .000 \\
\hline & Logarithm & .676 & 2.872 & 6167.549 & 8.249 & .000 & .000 & .000 \\
\hline & Power & .729 & .322 & 92.493 & .104 & .000 & .000 & .000 \\
\hline & S & .562 & .409 & 92.493 & .167 & .000 & .000 & .000 \\
\hline & Growth & .802 & .275 & 92.493 & .076 & .000 & .000 & .000 \\
\hline & Exponential & .802 & .275 & 92.493 & .076 & .000 & .000 & .000 \\
\hline \multirow[t]{19}{*}{ D. alatus } & $\mathrm{DBH}$ & & & & & & & \\
\hline & Linear & .791 & 4.237 & 14881.911 & 17.949 & .000 & .052 & .000 \\
\hline & Logarithm & .688 & 5.177 & 14881.911 & 26.802 & .000 & .002 & .000 \\
\hline & Power & .848 & .346 & 136.280 & .120 & .000 & .000 & .000 \\
\hline & S & .746 & .448 & 136.280 & .200 & .000 & .000 & .000 \\
\hline & Growth & .898 & .283 & 136.280 & .080 & .000 & .000 & .000 \\
\hline & $\begin{array}{l}\text { Exponential } \\
\text { TH }\end{array}$ & .898 & .283 & 136.280 & .080 & .000 & .000 & .000 \\
\hline & Linear & .895 & 2.321 & 8837.074 & 5.387 & .000 & .000 & .000 \\
\hline & Logarithm & .813 & 3.090 & 8837.074 & 9.548 & .000 & .001 & .000 \\
\hline & Power & .920 & .231 & 116.136 & .053 & .000 & .000 & .000 \\
\hline & S & .855 & .312 & 116.136 & .097 & .000 & .000 & .000 \\
\hline & Growth & .933 & .212 & 116.136 & .045 & .000 & .000 & .000 \\
\hline & $\begin{array}{l}\text { Exponential } \\
\mathrm{MH}\end{array}$ & .933 & .212 & 116.136 & .045 & .000 & .000 & .000 \\
\hline & Linear & .793 & 2.595 & 5629.773 & 6.733 & .000 & .010 & .000 \\
\hline & Logarithm & .711 & 3.066 & 5629.773 & 9.398 & .000 & .002 & .000 \\
\hline & Power & .882 & .299 & 130.943 & .089 & .000 & .000 & .000 \\
\hline & S & .811 & .378 & 130.943 & .143 & .000 & .000 & .000 \\
\hline & Growth & .901 & .273 & 130.943 & .075 & .000 & .000 & .000 \\
\hline & Exponential & .901 & .273 & 130.943 & .075 & .000 & .000 & .000 \\
\hline \multirow[t]{19}{*}{ A. excelsa } & $\mathrm{DBH}$ & & & & & & & \\
\hline & Linear & .867 & 4.434 & 19270.427 & 19.657 & .000 & .000 & .000 \\
\hline & Logarithm & .903 & 3.789 & 19270.427 & 14.355 & .000 & .000 & .000 \\
\hline & Power & .833 & .382 & 113.893 & .146 & .000 & .000 & .000 \\
\hline & S & .944 & .221 & 113.893 & .049 & .000 & .000 & .000 \\
\hline & Growth & .616 & .580 & 113.893 & .337 & .000 & .000 & .000 \\
\hline & $\begin{array}{l}\text { Exponential } \\
\text { TH }\end{array}$ & .616 & .580 & 113.893 & .337 & .000 & .000 & .000 \\
\hline & Linear & .786 & 2.941 & 5256.027 & 8.651 & .000 & .000 & .000 \\
\hline & Logarithm & .906 & 1.946 & 5256.027 & 3.785 & .000 & .929 & .000 \\
\hline & Power & .774 & .297 & 50.830 & .088 & .000 & .000 & .000 \\
\hline & $\mathrm{S}$ & .939 & .155 & 50.830 & .024 & .000 & .000 & .000 \\
\hline & Growth & .544 & .422 & 50.830 & .178 & .000 & .000 & .000 \\
\hline & $\begin{array}{l}\text { Exponential } \\
\text { MH }\end{array}$ & .544 & .422 & 50.830 & .178 & .000 & .000 & .000 \\
\hline & Linear & .781 & 2.535 & 3816.325 & 6.426 & .000 & .000 & .000 \\
\hline & Logarithm & .872 & 1.938 & 3816.325 & 3.757 & .000 & .025 & .000 \\
\hline & Power & .812 & .279 & 53.840 & .078 & .000 & .000 & .000 \\
\hline & $\mathrm{S}$ & .910 & .193 & 53.840 & .037 & .000 & .000 & .000 \\
\hline & Growth & .605 & .405 & 53.840 & .164 & .000 & .000 & .000 \\
\hline & Exponential & .605 & .405 & 53.840 & .164 & .000 & .000 & .000 \\
\hline
\end{tabular}


Table 6. Predicted growth size with $95 \%$ prediction intervals

\begin{tabular}{|c|c|c|c|c|c|c|c|c|c|c|c|c|c|c|c|c|c|c|}
\hline \multirow{2}{*}{$\begin{array}{c}\text { Age } \\
\text { (year) }\end{array}$} & \multicolumn{3}{|c|}{ H. brasiliensis } & \multicolumn{3}{|c|}{ H. odorata } & \multicolumn{3}{|c|}{ S. roxburghii } & \multicolumn{3}{|c|}{ S. macrophylla } & \multicolumn{3}{|c|}{ D. alatus } & \multicolumn{3}{|c|}{ A. Excelsa } \\
\hline & DBH & TH & MH & DBH & TH & MH & DBH & TH & MH & DBH & TH & MH & DBH & TH & MH & DBH & TH & MH \\
\hline 1 & $\begin{array}{l}2.10 \\
(1.31-3.34)\end{array}$ & $\begin{array}{l}3.34 \\
(2.43-4.57)\end{array}$ & $\begin{array}{l}2.82 \\
(1.91-4.16)\end{array}$ & $\begin{array}{l}3.06 \\
(1.74-5.38\end{array}$ & $\begin{array}{l}3.03 \\
(1.83-5.0\end{array}$ & $\begin{array}{l}1.74 \\
(.90-3.36)\end{array}$ & $\begin{array}{l}1.16 \\
(.59-2.28)\end{array}$ & $\begin{array}{l}3.83 \\
(2.60-5.64)\end{array}$ & $\begin{array}{l}2.37 \\
(1.40-3.40)\end{array}$ & $\begin{array}{l}3.70 \\
(180-7.61)\end{array}$ & $\begin{array}{l}4.66 \\
(283-767)\end{array}$ & $\begin{array}{l}3.14 \\
(182-541)\end{array}$ & $\begin{array}{l}2.95 \\
(168-517)\end{array}$ & $\begin{array}{l}2.94 \\
(1.93-4.48)\end{array}$ & 1.93 & .08 & $\begin{array}{l}0.41 \\
(0.29-0.58)\end{array}$ & 29 \\
\hline 2 & $\begin{array}{l}4.37 \\
(2.75-6.94)\end{array}$ & $\begin{array}{l}5.25 \\
(3.84-7.19)\end{array}$ & $\begin{array}{l}3.33 \\
(2.26-4.92)\end{array}$ & $\begin{array}{l}3.41 \\
(1.94-5.99)\end{array}$ & $\begin{array}{l}3.30 \\
(1.99-5.46)\end{array}$ & $\begin{array}{l}1.92 \\
(1.00-3.71)\end{array}$ & $\begin{array}{l}2.37 \\
(1.21-4.64)\end{array}$ & $\begin{array}{l}4.09-09+1) \\
(2.78-6.03)\end{array}$ & $\begin{array}{l}2.56 \\
(1.52-4.32)\end{array}$ & $\begin{array}{l}4.21 \\
(205-8.67)\end{array}$ & $8-8.34)$ & $\begin{array}{l}3.45 \\
(2.00-5.94)\end{array}$ & $\begin{array}{l}3.17 \\
(1.81-5.56)\end{array}$ & $\begin{array}{l}3.15 \\
(2.07-4.79)\end{array}$ & $\begin{array}{l}2.07 \\
(1.21-3.57)\end{array}$ & $\begin{array}{l}6 \\
69-2.100)\end{array}$ & $\begin{array}{l}3.25 \\
(2.37-4.45)\end{array}$ & 2.40 \\
\hline 3 & $\begin{array}{l}6.71 \\
(4.23-10.65)\end{array}$ & $\begin{array}{l}6.85 \\
(5.01-9.37)\end{array}$ & $\begin{array}{l}3.94 \\
(2.68-5.80)\end{array}$ & $\begin{array}{l}3.80 \\
(2.16-6.67)\end{array}$ & $\begin{array}{l}3.59 \\
(2.17-5.95)\end{array}$ & $\begin{array}{l}2.12 \\
(1.10-4.10)\end{array}$ & $\begin{array}{l}3.60 \\
(1.83-7.04)\end{array}$ & $\begin{array}{l}4.38 \\
(2.97-6.44)\end{array}$ & $\begin{array}{l}2.77 \\
(1.64-4.67)\end{array}$ & $\begin{array}{l}4.80 \\
(2.34-9.87)\end{array}$ & $\begin{array}{l}.51 \\
3.35-9.07)\end{array}$ & $\begin{array}{l}3.79 \\
(2.20-6.52)\end{array}$ & $\begin{array}{l}3.41 \\
(1.94-5.97)\end{array}$ & $\begin{array}{l}3.36 \\
(2.21-5.13)\end{array}$ & $\begin{array}{l}2.22 \\
(1.29-3.82)\end{array}$ & $\begin{array}{l}5.25 \\
(3.37-8.15)\end{array}$ & $\begin{array}{l}6.49 \\
(4.77-8.85)\end{array}$ & $\begin{array}{l}4.84 \\
(3.29-7.11)\end{array}$ \\
\hline 4 & $\begin{array}{l}9.11 \\
(5.74-14.76)\end{array}$ & $\begin{array}{l}8.27 \\
(6.05-11.31)\end{array}$ & $\begin{array}{l}4.66 \\
(3.16-6.86)\end{array}$ & $\begin{array}{l}4.23 \\
(2.41-7.43)\end{array}$ & $\begin{array}{l}3.92 \\
(2.36-6.48)\end{array}$ & $\begin{array}{l}2.34 \\
(1.21-4.52)\end{array}$ & $\begin{array}{l}4.84 \\
(2.47-9.46)\end{array}$ & $\begin{array}{l}4.68 \\
(3.18-6.89)\end{array}$ & $\begin{array}{l}2.99 \\
(1.77-5.05)\end{array}$ & $\begin{array}{l}5.46 \\
2.66-11.24)\end{array}$ & $\begin{array}{l}5.99 \\
(3.65-9.87)\end{array}$ & $\begin{array}{l}4.16 \\
(2.42-7.17)\end{array}$ & $\begin{array}{l}3.66 \\
(2.09-6.40)\end{array}$ & $\begin{array}{l}3.60 \\
(2.37-5.48)\end{array}$ & $\begin{array}{l}2.38 \\
(1.39-4.10)\end{array}$ & $\begin{array}{l}8.81 \\
(5.68-13.68)\end{array}$ & $\begin{array}{l}9.17 \\
(6.74-12.48)\end{array}$ & $\begin{array}{l}6.87 \\
(4.68-10.08)\end{array}$ \\
\hline 5 & $\begin{array}{l}11.54 \\
(7.26-18.32)\end{array}$ & $\begin{array}{l}9.58 \\
(7.00-13.10)\end{array}$ & $\begin{array}{l}5.50 \\
(3.74-8.11)\end{array}$ & $\begin{array}{l}4.72 \\
(2.68-8.27)\end{array}$ & $\begin{array}{l}4.27 \\
(2.58-7.07)\end{array}$ & $\begin{array}{l}2.58 \\
(1.34-4.99)\end{array}$ & $\begin{array}{l}6.09 \\
(3.11-11.90)\end{array}$ & $\begin{array}{l}5.00 \\
(3.40-7.37)\end{array}$ & $\begin{array}{l}3.23 \\
(1.92-5.46)\end{array}$ & $3-12.80)$ & $7-10.73)$ & $\begin{array}{l}4.57 \\
(2.66-7.87)\end{array}$ & $\begin{array}{l}3.94 \\
(2.24-6.88)\end{array}$ & $\begin{array}{l}3.85 \\
(2.53-5.86)\end{array}$ & $\begin{array}{l}2.56 \\
(1.49-4.40)\end{array}$ & $\begin{array}{l}12.03 \\
(7.75-18.66)\end{array}$ & $\begin{array}{l}11.29 \\
(8.30-15.36)\end{array}$ & $\begin{array}{l}8.48 \\
(5.78-12.43)\end{array}$ \\
\hline 6 & $\begin{array}{l}14.00 \\
(8.81-22.24)\end{array}$ & $\begin{array}{l}10.79 \\
(7.88-14.76)\end{array}$ & $\begin{array}{l}6.50 \\
(4.41-9.59)\end{array}$ & $\begin{array}{l}5.25 \\
(2.99-9.21)\end{array}$ & $\begin{array}{l}4.65 \\
(2.81-7.70)\end{array}$ & $\begin{array}{l}2.85 \\
(1.48-5.51)\end{array}$ & $\begin{array}{l}7.34 \\
(3.75-14.36)\end{array}$ & $\begin{array}{l}5.35 \\
(3.64-7.88)\end{array}$ & $\begin{array}{l}3.50 \\
(2.08-5.91)\end{array}$ & .46-14.58) & 09 & $\begin{array}{l}5.03 \\
(2.92-8.64)\end{array}$ & $\begin{array}{l}4.23 \\
(2.41-7.39)\end{array}$ & $\begin{array}{l}4.11 \\
(2.71-6.27)\end{array}$ & $(1.60-4.72)$ & $\begin{array}{l}14.81 \\
(9.54-22.97)\end{array}$ & $\begin{array}{l}12.96 \\
(9.53-17.63)\end{array}$ & $\begin{array}{l}9.75 \\
(6.645-14.30)\end{array}$ \\
\hline 7 & $\begin{array}{l}14.50 \\
(10.95-19.14)\end{array}$ & $\begin{array}{l}9.57 \\
(7.33-12.48)\end{array}$ & $\begin{array}{l}6.07 \\
(4.28-8.63)\end{array}$ & $\begin{array}{l}5.85 \\
(3.33-10.26\end{array}$ & $\begin{array}{l}5.07 \\
(3.06-8.39)\end{array}$ & $\begin{array}{l}3.15 \\
(1.64-6.09)\end{array}$ & $\begin{array}{l}8.61 \\
(4.39-16.83)\end{array}$ & $\begin{array}{l}5.72 \\
(3.89-8.43)\end{array}$ & $\begin{array}{l}3.78 \\
(2.24-6.39)\end{array}$ & $\begin{array}{l}8.07 \\
(3.94-16.60)\end{array}$ & $\begin{array}{l}7.71 \\
(4.70-12.70)\end{array}$ & $\begin{array}{l}5.52 \\
(3.21-9.49)\end{array}$ & $\begin{array}{l}4.55 \\
(2.59-7.93)\end{array}$ & $\begin{array}{l}4.40 \\
(2.90-6.70)\end{array}$ & $\begin{array}{l}2.94 \\
(1.71-5.06)\end{array}$ & $\begin{array}{l}17.17 \\
(11.07-26.64)\end{array}$ & $\begin{array}{l}14.30 \\
(10.52-19.46)\end{array}$ & $\begin{array}{l}10.78 \\
(7.35-1\end{array}$ \\
\hline 8 & 4. & 10 & $\begin{array}{l}6.19 \\
(4.36-8.80)\end{array}$ & $\begin{array}{l}6.52 \\
(3.71-11.43)\end{array}$ & $\begin{array}{l}5.53 \\
(3.34-9\end{array}$ & 3.48 & $\begin{array}{l}9.88 \\
(5.04-19.31)\end{array}$ & 6.12 & $\begin{array}{l}4.09 \\
(2.43-6.91\end{array}$ & 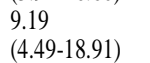 & 2) & $\begin{array}{l}6.06 \\
(3.52-\end{array}$ & $\begin{array}{l}4.88 \\
(2.78\end{array}$ & 0 & $=0,00$, & 7) & $\begin{array}{l}15 \\
(1\end{array}$ & 4) \\
\hline 9 & 2) & $\begin{array}{l}10.7 \\
8.2\end{array}$ & $\begin{array}{l}6.32 \\
(4.45-8.98)\end{array}$ & $\begin{array}{l}7.26 \\
(4.13-12.73)\end{array}$ & $\begin{array}{l}6.02 \\
(3.63-9.97)\end{array}$ & $\begin{array}{l}3.84 \\
(2.00-7.42)\end{array}$ & $9-21.80)$ & 6.54 & $\begin{array}{l}4.42 \\
(2.62-7.47)\end{array}$ & $-21.55)$ & 04) & $\begin{array}{l}6.66 \\
(3.87-11.45)\end{array}$ & $\begin{array}{l}5.25 \\
(2.98-9.156)\end{array}$ & $\begin{array}{l}5.03 \\
(3.32-7.67)\end{array}$ & 32) & 17) & $\begin{array}{l}16 \\
(12\end{array}$ & $\begin{array}{l}12.32 \\
(8.39-18.07)\end{array}$ \\
\hline 10 & $93-22.60)$ & $\begin{array}{l}11.31 \\
(8.66-14.74)\end{array}$ & $\begin{array}{l}6.44 \\
(4.54-9.16)\end{array}$ & $\begin{array}{l}8.09 \\
(4.60-14.18)\end{array}$ & $\begin{array}{l}6.56 \\
(3.96-10.86)\end{array}$ & $\begin{array}{l}4.24 \\
(2.20-8.19)\end{array}$ & $\begin{array}{l}12.43 \\
(6.34-24.31)\end{array}$ & $\begin{array}{l}7.00 \\
(4.76-10.31)\end{array}$ & $\begin{array}{l}4.78 \\
(2.84-8.08)\end{array}$ & $24.55)$ & 5-16.37) & $\begin{array}{l}7.32 \\
(4.25-12.58)\end{array}$ & $\begin{array}{l}5.64 \\
(3.21-9.83)\end{array}$ & $\begin{array}{l}5.38 \\
(3.55-8.20)\end{array}$ & 63 & $80)$ & $\begin{array}{l}17.09 \\
(12.56-2\end{array}$ & $\begin{array}{l}12.90 \\
(8.79-18.93)\end{array}$ \\
\hline 11 & 1 & $\begin{array}{l}11.83 \\
(9.05-15.41)\end{array}$ & $\begin{array}{l}6.57 \\
(4.63-9.35)\end{array}$ & $\begin{array}{l}9.01 \\
(5.12-15.79)\end{array}$ & $\begin{array}{l}7.15 \\
(4.32-11.84)\end{array}$ & $\begin{array}{l}4.68 \\
(2.43-9.05)\end{array}$ & $\begin{array}{l}13.71 \\
(6.99-26.82)\end{array}$ & $\begin{array}{l}7.48 \\
(5.09-11.02)\end{array}$ & $\begin{array}{l}5.16 \\
(3.07-8.74)\end{array}$ & (1) & & $\begin{array}{l}8.04 \\
(4.67-13.83)\end{array}$ & $\begin{array}{l}6.06 \\
(3.45-10.56\end{array}$ & $\begin{array}{l}5 . \\
(3\end{array}$ & 2.0 .207 & 83) & $\begin{array}{l}17 \\
(1 .\end{array}$ & 13 \\
\hline 12 & & $\begin{array}{l}12.32 \\
9.43-16.05\end{array}$ & $\begin{array}{l}6.71 \\
(4.73-9.54)\end{array}$ & & $\begin{array}{l}7.79 \\
(4.70-12.90)\end{array}$ & 517 & $\begin{array}{l}15.00 \\
(7.64-29.33)\end{array}$ & 8.00 & & & & & & & & & $\begin{array}{l}18.31 \\
013.46\end{array}$ & \\
\hline 13 & & & $\begin{array}{l}6.84 \\
(4.82-9.73)\end{array}$ & & $\begin{array}{l}8.49 \\
(5.12-14.06)\end{array}$ & ) & $\begin{array}{l}16.29 \\
(8.30-31.86)\end{array}$ & $\begin{array}{l}8.55 \\
(5.82-1\end{array}$ & $\begin{array}{l}6.04 \\
(3.59-10.22\end{array}$ & & & & & & & & ) $(1$ & 87) \\
\hline 1 & 20 & $\begin{array}{l}13.2 \\
(10\end{array}$ & $\begin{array}{l}6.98 \\
4.9\end{array}$ & $\begin{array}{l}12.4 \\
(7.0\end{array}$ & $\begin{array}{l}9.26 \\
(5.58\end{array}$ & $\begin{array}{l}6.30 \\
(3.28-12.20)\end{array}$ & $\begin{array}{l}17 \\
(8\end{array}$ & $\begin{array}{l}9.15 \\
(6.2\end{array}$ & $\begin{array}{l}6.53 \\
(3.88-1\end{array}$ & 2 & & .34) & $\begin{array}{l}7.52 \\
(4.2\end{array}$ & $\begin{array}{l}7.1 \\
(4\end{array}$ & & ) & ) 19 & \\
\hline 15 & 20.70 & $\begin{array}{l}13.6 \\
(10 .\end{array}$ & $\begin{array}{l}7.12 \\
(5.02-10.1\end{array}$ & $\begin{array}{l}13.89 \\
(7.87-20.31)\end{array}$ & $\begin{array}{l}10.09 \\
(6.08-16.70)\end{array}$ & $\begin{array}{l}6.95 \\
(3.62-13.48)\end{array}$ & $\begin{array}{l}18.87 \\
(9.62-36.9\end{array}$ & $\begin{array}{l}9.78 \\
(6.66-14.42)\end{array}$ & $\begin{array}{l}7.06 \\
(4.19-11.95)\end{array}$ & 83 & & $\begin{array}{l}11.71 \\
(6.79-20.15)\end{array}$ & $\begin{array}{l}8.09 \\
(4.59-14.06)\end{array}$ & $\begin{array}{l}7.52 \\
(4.97-1\end{array}$ & 5.15 & & $\begin{array}{l}19 \\
(1\end{array}$ & \\
\hline 16 & & $\begin{array}{l}14.0 \\
10 .\end{array}$ & $\begin{array}{l}7.27 \\
5.12-1\end{array}$ & $\begin{array}{l}15 \\
(8\end{array}$ & $\begin{array}{l}10.99 \\
(6.63-1\end{array}$ & & & & & & & & & & & & & \\
\hline 17 & 13) & $\begin{array}{l}14.50 \\
11.09\end{array}$ & $\begin{array}{l}7.41 \\
(5.23\end{array}$ & $\begin{array}{l}17.23 \\
(9.76-30.16)\end{array}$ & $\begin{array}{l}11.98 \\
(7.22-19.84)\end{array}$ & $\begin{array}{l}8.48 \\
(4.41-16.45)\end{array}$ & $\begin{array}{l}21.47 \\
(10.94-42.02)\end{array}$ & $\begin{array}{l}11.18 \\
(7.61-1\end{array}$ & $\begin{array}{l}8.25 \\
(4.90-13.98)\end{array}$ & 15 & & $\begin{array}{l}14 \\
(8\end{array}$ & $\begin{array}{l}9.34 \\
(5.30-\end{array}$ & $\begin{array}{l}8.60 \\
5.69\end{array}$ & $\begin{array}{l}5.9 \\
(3 .\end{array}$ & $\begin{array}{l}28 \\
(1\end{array}$ & 2 & 1 \\
\hline 18 & & 14.89 & $\begin{array}{l}7.56 \\
(5.33-10.76)\end{array}$ & 19.20 & $\begin{array}{l}13.06 \\
(7.87-21.63\end{array}$ & 9.36 & $\begin{array}{l}22.77 \\
(11.60-44 .\end{array}$ & & $\begin{array}{l}8.92 \\
(5.30-15.12)\end{array}$ & 6 & & & & & & & & \\
\hline 19 & & & $\begin{array}{l}7.72 \\
(5.44-1\end{array}$ & 21. & $\begin{array}{l}14.23 \\
(8.57-2\end{array}$ & & & & & & & & & & & & & \\
\hline 20 & . & $\begin{array}{l}15.64 \\
(11.97\end{array}$ & $\begin{array}{l}7.87 \\
(5.55-11.20)\end{array}$ & 23.83 & $\begin{array}{l}15.51 \\
(9.34-25.69)\end{array}$ & $\begin{array}{l}11.41 \\
(5.94-22.17)\end{array}$ & $\begin{array}{l}25.38 \\
(12.92-49\end{array}$ & $\begin{array}{l}13.67 \\
9.31-2\end{array}$ & $\begin{array}{l}10.42 \\
(6.20-17.68)\end{array}$ & 43.73 & 3) & $\begin{array}{l}18.74 \\
(10.82\end{array}$ & 11.59 & $\begin{array}{l}10.51 \\
(6.96-16.08)\end{array}$ & $\begin{array}{l}7.30 \\
(4.28-12.61)\end{array}$ & 3 & $\begin{array}{l}21.02 \\
15.45\end{array}$ & $\begin{array}{l}15.92 \\
10.84\end{array}$ \\
\hline 21 & & 16 & $\begin{array}{l}8.03 \\
(5.67-11 .\end{array}$ & 2 & $\begin{array}{l}16.90 \\
(10.18\end{array}$ & 12.59 & 26.69 & $\begin{array}{l}14.62 \\
(9.95-21.60)\end{array}$ & $\begin{array}{l}11.27 \\
(6.70-19.1\end{array}$ & 4980 & 2 & 2 & 1246 & $\begin{array}{l}11.24 \\
(7.44-17.21)\end{array}$ & $\begin{array}{l}7.83 \\
(4.59-13.53)\end{array}$ & & & \\
\hline 22 & & 16.36 & & 29.57 & 18.42 & & 28.00 & & & 56.72 & & & 13. & & & 31 & & \\
\hline 2. & & 5.70 & & 32.95 & 20.07 & $\begin{array}{l}1.24-35 \\
15.35 \\
17.99-2\end{array}$ & $\begin{array}{l}114.2 J-J \\
29.31 \\
14.92-5\end{array}$ & 16.72 & $\begin{array}{l}13.17 \\
6.82\end{array}$ & 64.59 & & & $\begin{array}{l}7.37-2 \\
14.38\end{array}$ & & $\begin{array}{l}4.92 \\
9.01 \\
5.28\end{array}$ & 89 & & \\
\hline 24 & & 17 & & & & & & & & & & & & & & & & \\
\hline & & & & & & & & & & & & & & & & & & \\
\hline 25 & & & 8.70 & 4080 & 23.84 & 18.71 & 31.94 & 19.11 & 15.39 & $7542)$ & & 2998 & 16.61 & 14.69 & 10.36 & 32.59 & 21.91 & \\
\hline
\end{tabular}


Table 7. Growth rate of DBH (cm year-1), TH $\left(\mathrm{m}^{-1}\right.$ year $\left.^{-1}\right)$ and $\mathrm{MH}(\mathrm{m} \text { year-1 })^{*}$

\begin{tabular}{|c|c|c|c|c|c|c|c|c|c|c|c|c|c|c|c|c|c|c|}
\hline \multirow{2}{*}{$\begin{array}{l}\begin{array}{l}\text { Age } \\
\text { (year) }\end{array} \\
\end{array}$} & \multicolumn{3}{|c|}{ H. brasiliensis } & \multicolumn{3}{|c|}{ H. odorata } & \multicolumn{3}{|c|}{ S. roxburghii } & \multicolumn{3}{|c|}{ S. macrophylla } & \multicolumn{3}{|c|}{ D. alatus } & \multicolumn{3}{|c|}{ A. excelsa } \\
\hline & DBH & TH & MH & DBH & TH & MH & DBH & TH & MH & DBH & TH & MH & DBH & TH & MH & DBH & TH & MH \\
\hline 1 & 2.273 & 1.917 & 0.513 & 0.349 & 0.272 & 0.181 & 1.209 & 0.265 & 0.192 & 0.514 & 0.408 & 0.310 & 0.220 & 0.204 & 0.140 & 1.775 & 2.844 & 2.108 \\
\hline 2 & 2.345 & 1.598 & 0.606 & 0.389 & 0.296 & 0.200 & 1.228 & 0.284 & 0.208 & 0.585 & 0.444 & 0.340 & 0.237 & 0.218 & 0.150 & 3.387 & 3.240 & 2.438 \\
\hline 3 & 2.394 & 1.421 & 0.716 & 0.433 & 0.323 & 0.221 & 1.240 & 0.303 & 0.224 & 0.666 & 0.483 & 0.374 & 0.254 & 0.233 & 0.161 & 3.568 & 2.680 & 2.030 \\
\hline 4 & 2.430 & 1.302 & 0.846 & 0.483 & 0.352 & 0.244 & 1.250 & 0.324 & 0.243 & 0.758 & 0.525 & 0.410 & 0.273 & 0.249 & 0.173 & 3.219 & 2.114 & 1.607 \\
\hline 5 & 2.460 & 1.215 & 1.000 & 0.538 & 0.383 & 0.269 & 1.257 & 0.347 & 0.262 & 0.864 & 0.571 & 0.451 & 0.294 & 0.267 & 0.185 & 2.776 & 1.673 & 1.275 \\
\hline 6 & 2.485 & 1.146 & 1.182 & 0.599 & 0.418 & 0.297 & 1.264 & 0.371 & 0.284 & 0.984 & 0.621 & 0.495 & 0.316 & 0.285 & 0.199 & 2.367 & 1.345 & 1.027 \\
\hline 7 & 0.933 & 0.617 & 0.123 & 0.667 & 0.455 & 0.328 & 1.269 & 0.397 & 0.307 & 1.120 & 0.675 & 0.544 & 0.339 & 0.305 & 0.213 & 2.020 & 1.100 & 0.840 \\
\hline 8 & 0.873 & 0.577 & 0.125 & 0.744 & 0.496 & 0.362 & 1.274 & 0.424 & 0.332 & 1.276 & 0.735 & 0.598 & 0.365 & 0.326 & 0.229 & 1.734 & 0.913 & 0.699 \\
\hline 9 & 0.823 & 0.544 & 0.128 & 0.828 & 0.541 & 0.400 & 1.278 & 0.453 & 0.358 & 1.453 & 0.799 & 0.657 & 0.392 & 0.349 & 0.245 & 1.499 & 0.769 & 0.589 \\
\hline 10 & 0.780 & 0.516 & 0.130 & 0.923 & 0.589 & 0.441 & 1.282 & 0.485 & 0.388 & 1.655 & 0.869 & 0.721 & 0.421 & 0.373 & 0.263 & 1.306 & 0.656 & 0.503 \\
\hline 11 & 0.743 & 0.492 & 0.133 & 1.028 & 0.642 & 0.487 & 1.286 & 0.518 & 0.419 & 1.884 & 0.945 & 0.792 & 0.453 & 0.399 & 0.282 & 1.146 & 0.566 & 0.434 \\
\hline 12 & 0.710 & 0.470 & 0.135 & 1.145 & 0.700 & 0.538 & 1.289 & 0.554 & 0.453 & 2.146 & 1.028 & 0.871 & 0.486 & 0.426 & 0.302 & 1.013 & 0.493 & 0.378 \\
\hline 13 & 0.682 & 0.451 & 0.138 & 1.276 & 0.763 & 0.594 & 1.292 & 0.593 & 0.490 & 2.444 & 1.118 & 0.956 & 0.523 & 0.456 & 0.324 & 0.901 & 0.433 & 0.332 \\
\hline 14 & 0.656 & 0.434 & 0.141 & 1.422 & 0.831 & 0.655 & 1.295 & 0.634 & 0.529 & 2.783 & 1.216 & 1.051 & 0.562 & 0.487 & 0.348 & 0.806 & 0.384 & 0.294 \\
\hline 15 & 0.633 & 0.419 & 0.144 & 1.584 & 0.906 & 0.724 & 1.297 & 0.678 & 0.572 & 3.169 & 1.323 & 1.154 & 0.604 & 0.521 & 0.373 & 0.726 & 0.342 & 0.262 \\
\hline 16 & 0.613 & 0.406 & 0.147 & 1.764 & 0.987 & 0.799 & 1.300 & 0.725 & 0.619 & 3.609 & 1.438 & 1.268 & 0.649 & 0.557 & 0.400 & 0.656 & 0.307 & 0.235 \\
\hline 17 & 0.594 & 0.393 & 0.150 & 1.965 & 1.076 & 0.882 & 1.302 & 0.775 & 0.669 & 4.110 & 1.564 & 1.393 & 0.697 & 0.596 & 0.429 & 0.596 & 0.277 & 0.212 \\
\hline 18 & 0.576 & 0.382 & 0.153 & 2.190 & 1.173 & 0.974 & 1.304 & 0.829 & 0.723 & 4.681 & 1.702 & 1.530 & 0.749 & 0.637 & 0.460 & 0.543 & 0.251 & 0.192 \\
\hline 19 & 0.560 & 0.371 & 0.156 & 2.439 & 1.278 & 1.075 & 1.306 & 0.886 & 0.782 & 5.331 & 1.851 & 1.681 & 0.805 & 0.681 & 0.494 & 0.498 & 0.228 & 0.175 \\
\hline 20 & 0.546 & 0.361 & 0.159 & 2.718 & 1.393 & 1.187 & 1.308 & 0.947 & 0.845 & 6.071 & 2.013 & 1.847 & 0.865 & 0.728 & 0.530 & 0.457 & 0.209 & 0.160 \\
\hline 21 & 0.532 & 0.352 & 0.162 & 3.027 & 1.518 & 1.311 & 1.310 & 1.013 & 0.914 & 6.914 & 2.189 & 2.029 & 0.930 & 0.779 & 0.568 & 0.422 & 0.191 & 0.147 \\
\hline 22 & 0.519 & 0.344 & 0.165 & 3.373 & 1.654 & 1.447 & 1.312 & 1.083 & 0.988 & 7.874 & 2.381 & 2.229 & 0.999 & 0.833 & 0.609 & 0.390 & 0.176 & 0.135 \\
\hline 23 & 0.507 & 0.336 & 0.169 & 3.757 & 1.803 & 1.598 & 1.313 & 1.158 & 1.068 & 8.967 & 2.590 & 2.448 & 1.074 & 0.890 & 0.653 & 0.362 & 0.163 & 0.125 \\
\hline 24 & 0.496 & 0.329 & 0.172 & 4.186 & 1.965 & 1.764 & 1.315 & 1.239 & 1.155 & 10.212 & 2.817 & 2.690 & 1.154 & 0.952 & 0.701 & 0.336 & 0.151 & 0.116 \\
\hline
\end{tabular}


Table 8. Example of using prediction results to calculate the ecosystem services quantity and values for individual years

\begin{tabular}{|c|c|c|c|c|c|c|c|c|c|c|c|c|}
\hline \multirow{3}{*}{ Species } & \multicolumn{6}{|c|}{ At 10-year age } & \multicolumn{6}{|c|}{ At 20-year age } \\
\hline & \multicolumn{3}{|c|}{ Quantity $\left(\right.$ ha $\left.^{-1}\right)$} & \multicolumn{3}{|c|}{ Value (USD ha' ${ }^{-1}$ ) } & \multicolumn{3}{|c|}{ Quantity $\left(\right.$ ha $\left.^{-1}\right)$} & \multicolumn{3}{|c|}{ Value (USD ha-1) } \\
\hline & $\begin{array}{c}\mathrm{CO}_{2} \\
\left(\mathrm{tCO}_{2} \mathrm{eq}\right) \\
\end{array}$ & $\begin{array}{c}\mathrm{O}_{2} \\
\left(\mathrm{~kg} \mathrm{O}_{2}\right) \\
\end{array}$ & $\begin{array}{c}\text { Timber } \\
\text { volume }\left(\mathbf{m}^{3}\right)\end{array}$ & $\mathrm{CO}_{2}$ & $\mathrm{O}_{2}$ & Timber & $\begin{array}{c}\mathrm{CO}_{2} \\
\left(\mathrm{tCO}_{2} \mathrm{eq}\right) \\
\end{array}$ & $\begin{array}{c}\mathrm{O}_{2} \\
\left(\mathrm{~kg} \mathrm{O}_{2}\right) \\
\end{array}$ & $\begin{array}{c}\text { Timber } \\
\text { volume }\left(\mathbf{m}^{\mathbf{3}}\right)\end{array}$ & $\mathrm{CO}_{2}$ & $\mathrm{O}_{2}$ & Timber \\
\hline H. brasiliensis & 15.4 & 10725 & 118.5 & 433.194 & 5362.5 & 4399.5 & 18.9 & 10889.5 & 276.5 & 529.9 & 6560 & 10206.6 \\
\hline H. odorata & 0.6 & 392.2 & 1.7 & 15.8 & 196.1 & 894.4 & 9.2 & 6431.2 & 40.1 & 259.8 & 3215.6 & 20872.1 \\
\hline S. roxburghii & 1.3 & 931.4 & 4.6 & 37.6 & 465.7 & 2122.3 & 5.4 & 3790.1 & 41.6 & 153.1 & 1895 & 19305.6 \\
\hline S. macrophylla & 2 & 1366 & 6.4 & 55.2 & 683 & 2644.4 & 47.9 & 3350.55 & 222.1 & 1347.1 & 16675 & 91145.5 \\
\hline D. alatus & 0.2 & 112.3 & 0.7 & 4.5 & 56.2 & 190.7 & 1.1 & 787.5 & 6.1 & 31.8 & 393.7 & 1621.8 \\
\hline A. excelsa & 4.2 & 2922.2 & 40.2 & 118 & 1461.1 & 13096.4 & 2.3 & 1570.8 & 92.5 & 63.4 & 785.4 & 301214 \\
\hline
\end{tabular}

Note: The figures are in that particular individual year. We use the general practiced density of $H$. Brasiliensis at 475 trees ha $^{-1}$ and five species of intercropping at 47 trees $\mathrm{ha}^{-1}$. Carbon dioxide. The annual carbon dioxide sequestration ha ${ }^{-1}$ was calculated from this equation: (BIT x 0.47) x 3.67 (BIT; biomass increment, 0.47 is carbon conversion factor (Eggleston et al. 2014) and 3.67 is carbon dioxide conversion factor (Meepol 2010)). The price of carbon assumed the price of $\mathrm{CO}_{2}$ European Emission Allowances (Insider incorporated 2020). Oxygen production. The oxygen production was calculated from this equation: BIT x 1.2 (BIT; biomass increment, 1.2; oxygen conversion factor) (Yolasiğmaz and Keleş 2009). The price of oxygen was the market sale price of oxygen from hospitals in Songkhla province (Sathing Phra Hospital 2020; Somdejprabororomrachineenart Natawee Hospital 2020). Timber. Timber volume was calculated from $\mathrm{V}=0.42 \times \mathrm{BA} \times \mathrm{MH}(\mathrm{V}$; timber volume, 0.42 ; coefficients of shape tree stem, BA; tree basal area at breast height and MH; tree merchantable height) (Magnussen 2004). The timber prices of economic forest trees were used according to the Royal Forest Department (2016), while the timber price of H. brasiliensis was from the Rubber Authority of Thailand (2019). The prices were adjusted using the consumer price index and the costs of logging were subtracted to derive the net value (economic forest trees logging costs were from Roongtawanreongsri et al. (2007), and H. brasiliensis was from the Rubber Authority of Thailand (2017). Biomass increment. The annual biomass increment was calculated from this equation: $\mathrm{B}_{\mathrm{t}+1}-\mathrm{B}_{\mathrm{t}}(\mathrm{B}$; biomass, $\mathrm{t}$; time), Biomass was calculated from the sum of aboveground and belowground biomass. Aboveground biomass was calculated from the equation in Tsutsumi et al. (1983): $\mathrm{W}_{\mathrm{s}}=0.0509\left(\mathrm{DBH}^{2} \times \mathrm{TH}\right)^{0.919}, \mathrm{~W}_{\mathrm{b}}=0.00893\left(\mathrm{DBH}^{2} \times \mathrm{TH}\right)^{0.977}, \mathrm{~W}_{\mathrm{l}}=0.0140\left(\mathrm{DBH}^{2} \mathrm{x} \mathrm{TH}\right)^{0.669}$ and $\mathrm{W}_{\mathrm{t}}=\mathrm{W}_{\mathrm{s}}+\mathrm{W}_{\mathrm{b}}+\mathrm{W}_{\mathrm{l}}$. Belowground biomass calculated from this equation: $\mathrm{W}_{\mathrm{r}}=\mathrm{W}_{\mathrm{t}} \times 0.24\left(\mathrm{DBH}\right.$; diameter at breast high, $\mathrm{TH}$; total height, $\mathrm{W}_{\mathrm{s}}$ : stem biomass, $\mathrm{W}_{\mathrm{b}}$; branch biomass, $\mathrm{W}_{\mathrm{l}}$; Leaf biomass, $\mathrm{W}_{\mathrm{t}}$; aboveground biomass, $\mathrm{W}_{\mathrm{r}}$; belowground biomass and 0.24; root/shoot ration in tropical zone (Cairns et al. 1997). The exchange rate was 1 USD = 32.4 Baht on 27 March 2020 (Bank of Thailand 2020).

Table 9. Comparison between the models' prediction and the observed data from other studies

\begin{tabular}{|c|c|c|c|c|c|c|c|}
\hline \multirow[t]{2}{*}{ Tree } & \multirow[t]{2}{*}{ Age } & \multirow{2}{*}{$\begin{array}{c}\text { Area } \\
\text { (province) }\end{array}$} & \multirow[t]{2}{*}{ References } & \multicolumn{2}{|c|}{ Result of other studies } & \multicolumn{2}{|c|}{$\begin{array}{c}\text { Result of prediction in } \\
\text { this study }\end{array}$} \\
\hline & & & & DBH $(\mathbf{c m})$ & TH (m) & DBH $(\mathbf{c m})$ & TH (m) \\
\hline \multirow[t]{3}{*}{ H. brasiliensis } & 5.5 & Songkhla & Booranatam et al. (2003) & 14.78 & - & 13.43 & - \\
\hline & 6.5 & Krabi & & 14.90 & - & 14.18 & - \\
\hline & 9 & Yala & & 19.39 & - & 16.45 & - \\
\hline \multirow[t]{4}{*}{ S. macrophylla } & 4.5 & Krabi & Booranatam et al. (2003) & 8.12 & - & 5.83 & - \\
\hline & 5.5 & Yala & & 9.90 & - & 6.64 & - \\
\hline & 7 & Songkhla & & 9.08 & - & 8.07 & - \\
\hline & $9^{1}$ & Prachuap Khiri Khan & Sathapong (1970) & 10 & 10.20 & 10.47 & 9.12 \\
\hline \multirow[t]{6}{*}{ A. excelsa } & 5.5 & Yala & Booranatam et al. (2003) & 9.62 & - & 13.47 & - \\
\hline & 7 & Songkhla & & 9.08 & - & 17.17 & - \\
\hline & 9.5 & Yala & & 10.75 & - & 21.70 & - \\
\hline & $5^{2}$ & Nakhon Si Thammarat & Phartnakorn and & 15.07 & 10.30 & 12.03 & 11.29 \\
\hline & $8^{2}$ & & Jirasuktaveeku (1998) & 21.39 & 13.41 & 19.2 & 15.40 \\
\hline & $11^{2}$ & & & 25.08 & 15.89 & 23.7 & 17.74 \\
\hline H. odorata & $17^{3}$ & Nakhon Ratchasima & Sakai et al. (2010) & 14.47 & 11.60 & 17.23 & 11.98 \\
\hline D. alatus & $20^{4}$ & Nakhon Ratchasima & Sakai et al. (2010) & 11.90 & 10.95 & 11.59 & 10.51 \\
\hline
\end{tabular}




\section{ACKNOWLEDGEMENTS}

This research was partly supported by the National Research Council of Thailand. The authors gratefully appreciate the help of 39 rubber farmers who allowed researchers to collect data from their farms.

\section{REFERENCES}

Bank for Agriculture and Agricultural Cooperatives. 2015. Tree bank. https://www.baac.or.th/treebank/baac-tree-bank-2015.pdf [Thai]

Bank of Thailand. 2020. Weighted-average Interbank Exchange Rate. https://www.bot.or.th/english/_layouts/application/exchangerate/exch angerate.aspx

Barbier E, Baumgärtner S, Chopra K, Costello C, Duraiappah A, Hassan R, Kinzig K, Lehman M, Pascual U, Polasky S, Perrings C. 2009. The valuation of ecosystem services. In: Naeem S, Bunker DE, Hector A Loreau M, Perrings C (eds) Biodiversity, Ecosystem Functioning, and Human Wellbeing: An Ecological and Economic Perspective. Oxford University Press.

Brooks RT, Kyker-Snowman TD. 2008. Forest floor temperature and relative humidity following timber harvesting in southern New England, USA. For Ecol Manag 254 (1): 65-73.

Booranatam W, Jantama A, Jantama P, Pachana P, Bamrungwong P, Petying P, Boonmorakot P. 2003. Planting some economic forest trees as intercropping in rubber plantation. Rubber Research Institute of Thailand, Department of Agriculture, Bangkok, Thailand. [Thai]

Brack C. 1999. Measuring parts of a single tree. https://fennerschoolassociated.anu.edu.au/mensuration/tree.htm

Brown S, Gillespie AJR, Lugo AE. 1989. Biomass estimation methods for tropical forests with applications to forest inventory data. For Sci 35 (4): 881-902.

Bumrungsri S, Sawangchote P, Tapedontree J, Nattharom N, Bauloi K, Chatchai N, Billasoy S. 2011. Litterfall and decomposition rate, density of earthworm, carbon storage, diversity of birds and bats in rubber agroforestry and monoculture rubber plantation at Thamod District, Phatthalung Province. Department of Biology, Faculty of Science, Prince of Songkla University, Songkhla, Thailand. [Thai]

Cairns M, Brown S, Helmer E, Baumgardner G. 1997. Root biomass allocation in the world's upland forests. Oecologia 111: 1-11.

Cameron AC, Windmeijer FAG. 1997. An R-squared measure of goodness of fit for some common nonlinear regression models. J Econometrics 77 (2): 329-342.

Cao QV. 2004. Annual tree growth prediction from periodic measurements. In: Proceedings of the $12^{\text {th }}$ biennial southern silvicultural research conference in Biloxi, Beau Rivage Resort and Casino, 24-28 February 2003

Charernjiratragul S, Palakorn S, Romyen A. 2015. Practical knowledge and lessons learned from driving the policy on expanding the area for the rubber-based intercropping systems. J Soc Dev 17: 35-50.

Chugamnerd S. 1998. Competitive Impacts of Rattan (Calamus spp.) on rubber (Hevea brasiliensis Muell. Arg.) under Intercropping System [Dissertation]. Prince of Songkla University, Songkhla. [Thai]

Ciceu A, Popa I, Leca S, Pitar D, Chivulescu S, Badea O. 2020. Climate change effects on tree growth from Romanian forest monitoring Level II plots. Sci Total Environ 698: 1-13.

Climatological Center. 2020. Thirty years climate statistics. http://climate.tmd.go.th/statistic/stat30y

Devaranavadgi SB, Bassappa S, Jolli RB, Wali SY, Bagli AN. 2013. Height-age growth curve modelling for different tree speciesin drylands of north karnataka. Global J Sci Front Res Agric Vet Sci 13 (1): $11-21$.

Eggleston S, Buendia L, Miwa K, Ngara T, Tanabe K. 2014. 2006 IPCC guidelines for National greenhouse gas inventories. https://www.ipcc nggip.iges.or.jp/public/2006gl/pdf/4_Volume4/V4_04_Ch4_Forest_L and.pdf

Fernández MP, Basauri J, Madariaga C, Menéndez-Miguélez M, Olea R, Zubizarreta-Gerendiain A. 2017. Effects of thinning and pruning on stem and crown characteristics of radiata pine (Pinus radiata D. Don). IForest 10 (2): 383-390.
Forestry Research Center. 2009. Study Project on Tree Plantation Promotion for Long-Term Saving. Faculty of Forestry, Kasetsart University, Bangkok, Thailand. [Thai]

George S, Suresh P, Wahid P, Nair RB. Punnoose K. 2009. Active root distribution pattern of Hevea brasiliensis determined by radioassay of latex serum. Agrofor Syst 76 (2): 275-281.

Golley FB. 1983. Nutrient cycling and nutrient conservation. In: Golley FB (eds). Tropical Rain Forest Ecosystems. Amsterdam, Netherlands.

Grogan J, Mark Schulze M, Jurandir G. 2010. Survival, growth and reproduction by big-leaf mahogany (Swietenia Macrophylla) in open clearing vs. forested conditions in Brazil. New For 40 (3): 335-347.

Hongthong B. 1991. Growth of 6 Dipterocarp species under different shade. http://app.dnp.go.th/opac/multimedia/research/1110_40.pdf [Thai]

Insider incorporated, Finanzen.net Gesellschaft mit beschränkter Haftung. 2020. CO2 European emission allowances in USD historical prices. https://markets.businessinsider.com/commodities/historicalprices/co2-european-emissionallowances/euro/3.1.2020_3.4.2020?fbclid=iwar2ah28gzcoc25ivztllpf 4f-z-va3ayiplzbenmbr8s98ocxujtj4teq_4

Islam M, Salim SH, Kawsar MH, Rahman M. 2016. The effect of soil moisture content and forest canopy openness on the regeneration of Dipterocarpus turbinatus C.F. Gaertn. (Dipterocarpaceae) in a protected forest area of Bangladesh. Trop Ecol 57 (3): 455-464.

Kittitornkool J, Bumrungsri S, Kheowvongsri P, Tongkam P, Waiyarat R, Nattharom N, Uttamunee W. 2014. A comparative study of integrated dimensions of sustainability between agroforest and monoculture rubber plantations. https://www.biodconference.org/wp-content/ uploads/2017/03/12.-page-073-078.pdf. [Thai]

Kumar BM, Nair PKR. 2011. Carbon Sequestration Potential of Agroforestry Systems: Opportunities and Challenges. Springer Science \& Business Media, New York.

Linder S. 1981. Understanding and predicting tree growth. https://pub.epsilon.slu.se/5287/1/SFS160.pdf?fbclid=IwAR2MjFV_m z9gxYRbCR0kKyRLJcw5AFPDUBn3ZDB2AVAX1AVzzyW6Jy6xe f4

Lohmann U, Sausen R, Bengtsson L, Cubasch U, Perlwitz J, Roeckner E. 1993. The Koppen climate classification as a diagnostic tool for general circulation models. Clim Res 3 (3): 177-193.

Luoma V, Saarinen N, Wulder MA, White JC, Vastaranta M, Holopainen M, Hyyppä J. 2017. Assessing precision in conventional field measurements of individual tree attributes. Forests 8 (2): 1-16.

Maeght JL, Rewald B, Pierret A. 2013. How to study deep roots-and why it matters. Front Plant Sci 4: 1-14.

Maggiotto SR, de Oliveira D., Marur CJ, Stivari, SSM, Leclerc M, Wagner-Riddle C. 2014. Potencial de sequestro de carbono em seringais no noroeste do Paraná, Brasil. Acta Scientiarum Agronomy 36 (2): 239-245. [Portugueese]

Magnussen S. 2004. Volume estimation. In: Knowledge Reference for National Forest Assessments-Modeling for Estimation and Monitoring. FAO, Rome. http://www.fao.org/forestry/17109/en/

Meepol W. 2010. Carbon Sequestration of Mangrove Forests at Ranong Biosphere Reserve. J For Manag 4 (7): 33-47. [Thai]

Ministry of Natural Resources and Environment. 2018. The project for the promotion of economic forest tree for sustainable economic social and environmental. Ministry of Natural Resources and Environment, Bangkok. http://www.mnre.go.th/th/infographic/detail/341 [Thai]

Ogawa H, Yoda K, Ogino K, Kira T. 1965. Comparative ecological studies on three main types of forest vegetation in Thailand. II. Plant Biomass. Nat Life Southeast Asia 4: 49-80.

Özkan U, Gökbulak F. 2017. Effect of vegetation change from forest to herbaceous vegetation cover on soil moisture and temperature regimes and soil water chemistry. Catena 149 158-166.

Phartnakorn J, Jirasuktaveekul W. 1998. Study on growth and yield of Azadirachta excelsa (Jack) Jacobs at Phipun District, Nakhon Si Thammarat Province. http://frc.forest.ku.ac.th/frcdatabase/bulletin/ ws_document/R104701.pdf. [Thai]

Poosaksai P, Diloksumpun S, Poolsiri R, Chuntachot C. 2018. Biomass and carbon storage of four forest tree species at Prachuap Khiri Khan Silvicultural Research Station, Prachuap Khiri Khan Province. Thai J For 37 (2): 13-26. [Thai]

Priyadarshan PM. 2011. Biology of Hevea rubber. CAB International, Wallingford, UK

Roongtawanreongsri S, Darnsawasdi, Gampoo P. 2007. Economic Valuation of Timber from Khao Hua Chang, Tamot Sub-District, 
Tamot District, Patthalung Province. Thammasat Economic Journal. 25 (1):-. [Thai]

Roo Q, Negreros-castillo P, Mize CW. 2014. Mahogany growth and mortality and the relation of growth to site characteristics in a natural forest in Quintana Roo, Mexico. For Sci 60 (5): 907-913.

Royal Forest Department. 2016. Prices of imported logs and sawn timber B.E. 2559. Royal Forest Department, Bangkok. http://forestinfo.forest.go.th/Content/file/stat2559/Table\% 2022.pdf [Thai]

Rubber Authority of Thailand. 2012. The rubber replanting aid fund act B.E. 2530. Rubber Authority of Thailand, Bangkok. [Thai]

Rubber Research Institute of Thailand. 2017. Calculation to estimate the price of rubber wood in the rubber plantations before felling. Rubber Research Institute of Thailand, Bangkok. https://km.raot.co.th/kmknowledge/detail/222 [Thai]

Rubber Research Institute of Thailand. 2018. The academic information of Para rubber B.E 2561. Rubber Research Institute of Thailand, Bangkok. http://online.pubhtml5.com/lfcj/oubi/\#p=1 [Thai]

Saaludin N, Harun S, Yahya Y, Ahmad WSCW. 2014. Modeling individual tree diameter increment for Dipterocarpaceae and nonDipterocarpaceae in tropical rainforest. J Res Agric Anim Sci 2 (3): 18.

Sakai A, Visaratana T, Vacharangkura T. 2010. Size distribution and morphological damage to 17-yar-old Hopea odorata Roxb. planted in fast-growing tree stands in Northeast Thailand. Thai J For 29 (3): 1625. [Thai]

Sakai A, Visaratana T, Vacharangkura T, Thai-Ngam R, Nakamura S. 2014. Growth performance of four dipterocarp species planted in a Leucaena leucocephala plantation and in an open site on degraded land under a tropical monsoon climate. Japan Agric Res Quart 48 (1): 95-104.

Sathapong P. 1970. Growth of Mahogany. http://forprod.forest.go.th/forprod/ebook/FastGrowingTree/pdf/nาเเติบโต ของไม้มะฮอกกานีบบเล็ก.pdf [Thai]

Sathing Phra Hospital. 2020. Report of approval for medical supplies payment B.E. 2563. Sathing Phra Hospital, Songkhla, Thailand. [Thai]

Shono K, Snook LK. 2006. Growth of big-leaf mahogany (Swietenia macrophylla) in natural forests in Belize. J Trop For Sci 18 (1): 66 73.

Silpi U, Thaler P, Kasemsap P, Lacointe A, Chantuma A, Adam B, Gohet E, Thanisawanyangkura S, Améglio, T 2006. Effect of tapping activity on the dynamics of radial growth of Hevea brasiliensis trees. Tree Physiol 26 (12): 1579-1587.

Somdejprabororomrachineenart Natawee Hospital. 2020. Report of approval for medical supplies payment B.E. 2563 Somdejprabororomrachineenart Natawee Hospital, Songkhla, Thailand. [Thai]

Swift MJ, Anderson JM. 1989. Decomposition. In: Lieth H, Werger M (eds). Tropical Rain Forest Ecosystems: Biogeographical and Ecological Studies. Amsterdam, Netherlands.

Takimoto A, Nair PKR, Nair VD. 2008. Carbon stock and sequestration potential of traditional and improved agroforestry systems in the West African Sahel. Agric Ecosyst Environ 125 (1): 159-166.
Tamchai T, Suksawang S. 2017. Relationships between diameter at breath height and total height of trees in Kaeng Krachan forest complex, Thailand. Thai For Ecol Res J 1 (1): 27-34. [Thai]

The Intergovernmental Panel on Climate Change, 2006. 2006 IPCC guidelines for national greenhouse gas inventories. https://www.ipccnggip.iges.or.jp/public/2006gl/vol4.html

Toledo M, Poorter L, Peña-Claros M, Alarcón A, Balcázar J, Leaño, C, Licona, Juan C, Llanque O, Vroomans V, Zuidema P, Bongers, F. 2011. Climate is a stronger driver of tree and forest growth rates than soil and disturbance. J Ecol 99: 254-264.

Tong PS, Ng FSP. 2008. Effect of light intensity on growth, leaf production, leaf lifespan and leaf nutrient budgets of Acacia mangium, Cinnamomum iners, Dyera costulata, Eusideroxylon zwageri and Shorea roxburghii. J Trop For Sci 20 (3): 218-234.

Trephattanasuwan P, Diloksumpun S, Staporn D, Ratanakaew J. 2008. Carbon storage in biomass of some tree species planted at the PuParn Royal Development Study Centre, Sakon Nakhon Province. http://frc.forest.ku.ac.th/frcdatabase/bulletin/ws_document/R195301.p df [Thai]

Tsutsumi T, Yoda K, Dhanmanonda P, Prachaiyo B. 1983. Forest: Felling, burning and regeneration. In Kyuma K, Pairintra C (eds). Shifting Cultivation: An Experiment at Nam Phrom, Northeast Thailand and Its Implications for Upland Farming in the Monsoon Tropics. Bangkok, Thailand.

Villamor GB, Le QB, Djanibekov U, van Noordwijk M, Vlek PLG. 2014. Biodiversity in rubber agroforests, carbon emissions, and rural livelihoods: an agent-based model of landuse dynamics in lowland Sumatra. Environ Model Software 61: 155-165.

Viriyabuncha C, Ratanaporncharern W, Mungklarat C, Pianhanuruk P. 2004. Biomass and Growth of some Economic Tree Species for Estimate Carbon Accumulation in Plantation. http://frc.forest.ku.ac.th /frcdatabase/bulletin/Document/14.Chingchai.pdf. [Thai]

Visaratana T, Kiratiprayoon S, Pitpreecha K, Vutivijarn T, Kumpan T, Phatong S, Nakamura S. 1991. Probability for planting of Dalbergia cochinchinensis, Afzelia xylocarpa, Dipterocarpus alatus and Hopea odorata under canopy of Leucaena leucocephala and opened site. Royal Forest Department, Bangkok, Thailand. [Thai]

Wasserman, L. 2004. All of Statistics: A concise course in statistical inference. Springer Science and Business Media, USA.

Westfall JA, Laustsen KM. 2006. A merchantable and total height model for tree species in Maine. Northern J Appl For 23: 241-249.

Wibawa G, Joshi L, Van Noordwijk M, Penot EA. 2007. Rubber-based Agroforestry Systems (RAS) as Alternatives for Rubber Monoculture System. https://agritrop.cirad.fr/535426/1/document_535426.pdf

Witthawatchutikul P. 1993. Agroforestry system in para-rubber plantation. Thai J For 12 159-167. [Thai]

Yolasiğmaz HA, Keleş S. 2009. Changes in carbon storage and oxygen production in forest timber biomass of Balci Forest Management Unit in Turkey between 1984 and 2006. Afr J Biotechnol 8 (19): 48724883.

Yunis H, Elad Y, Mahrer Y. 1990. Effects of air temperature, relative humidity and canopy wetness on gray mold of cucumbers in unheated greenhouses. Phytoparasitica 18 (3): 203-215 